\title{
Jens Klose and Peter Tillmann* COVID-19 and Financial Markets: A Panel Analysis for European Countries
}

https://doi.org/10.1515/jbnst-2020-0063

Received December 1, 2020; accepted February 9, 2021

\begin{abstract}
In order to fight the economic consequences of the COVID-19 pandemic, monetary and fiscal policymakers announced a large variety of support packages which are often unprecedented in size. In this paper, we provide an empirical analysis of the responses of European financial markets to these policy announcements in the spring of 2020. We assemble a granular set of more than 400 policy announcements, both at the national and the European level. We also differentiate between the first announcement in a series of policies and the subsequent announcements because the initial steps were often seen as bad news about the state of the economy. In a panel model, we find that monetary policy, in particular, through asset purchases, is effective in easing the pressure on governmental finances. Stock prices are particularly sensitive to the suspension of the Stability and Growth Pact. Fiscal policy becomes more effective when monetary announcements fall on the same day. We also find sizable cross-border effects of policy announcements.
\end{abstract}

Keywords: event study, announcements, fiscal policy, monetary policy, European Monetary Union

JEL classification: E44, E52, E62

\section{Introduction}

The outbreak of the novel Coronavirus in China and East Asia at the beginning of 2020 forced authorities to take drastic measures to contain the spread of COVID-19. These measures led to a sharp reduction in economic activity. Initially, the

\footnotetext{
We thank the editor and two anonymous reviewers for helpful suggestions and seminar participants in Gießen for critical discussions. Moritz Grebe, Sinem Kandemir and Anisa Tiza Mimun provided very helpful research assistance.
}

*Corresponding author: Peter Tillmann, Justus-Liebig-University, Gießen, Germany, E-mail: peter.tillmann@wirtschaft.uni-giessen.de

Jens Klose, THM Business School, Gießen, Germany, E-mail: jens.klose@w.thm.de 
economic fallout from the lockdown measures was mostly contained to Asian economies. This changed with the spread of the virus to the rest of the world in February and March 2020. Restrictions on cross-border travel, shelter-in-place orders and a reduction of public life to a minimum have a strong impact on economic activity. As a result, institutions such as the European Commission or the International Monetary Fund expect most advanced economies to enter the most severe recession since the Great Depression. ${ }^{1}$ This economic burden comes on top of death toll and the global health impact.

In many economies, monetary and fiscal policy, both at the domestic level and the supranational level, stepped in to support firms, financial institutions and households. Examples include European Central Bank's (ECB) Pandemic Emergency Purchase Programme (PEPP) worth 750 billion euro and the European Commission's SURE (Support mitigating Unemployment Risks in Emergency) program.

The aim of this paper is to provide an early assessment of the effectiveness of these policy measures. It is certainly too early to evaluate the transmission of rescue and stimulus packages to the real economy. For that we would need long data series on growth and employment. Instead, we conduct an event study using daily data and shed light on the response of financial markets to the announcement of those policies. We study the response of stock and bond markets. If markets believe the support packages to be effective, stock prices should rise on impact. If investors discount the future budgetary burden implied by fiscal stimulus measures, bond yields should increase. However, if markets believe a fiscal action to bring the economy back on a sustainable growth path, even declining bond yields are possible.

We restrict the analysis to a large set of European countries. Across Europe, the outbreak of COVID-19 has not been perfectly synchronized. Thus, there is a great variation of national fiscal policy responses to the crisis. In addition, there are supranational policy responses from the ECB, the European Commission and the Eurogroup. This allows us to assess the relative effectiveness of national versus supranational policy steps. We estimate a number of panel regressions with daily stock returns and changes in government bond yields. To explain the adjustment of financial markets, we construct a number of dummy variables that reflect the different layers of policy responses. We measure the reduction of economic activity with data from the Google Community Movement Report that tracks the decline in mobility patterns relative to normal.

As one important contribution, this paper uses a detailed data set of policy announcements. In particular, we allow for announcements of monetary policy,

1 See https://ec.europa.eu/info/business-economy-euro/economic-performance-and-forecasts/ economic-forecasts/spring-2020-economic-forecast-deep-and-uneven-recession-uncertain-recovery_en and https://www.imf.org/en/Publications/WEO/Issues/2020/04/14/weo-april-2020. 
national fiscal policy and fiscal policy at the European level. For our dataset, we manually select and classify over 400 monetary and fiscal policy events across European countries. After the outbreak of the pandemic, research started to summarize a wide array of information on COVID-related policy measures in single indicators, i.e., the Oxford COVID-19 Government Response Tracker, ${ }^{2}$ the Oxford Supertracker $^{3}$ or the data provided by Cheng et al. (2020). Our data have two advantages compared to these initiatives. First, our dataset covers monetary and fiscal policy measures, not just public health policies or restrictions on public life. Second, our data allow to study the responses to granular policy announcements rather than a summary indicator of multiple announcements.

We further split these policies into different branches of policies. For example, we allow for announcement of asset purchases by the central banks and relaxations in banks' access to refinancing through the central banks to have different coefficients. Furthermore, the market response to fiscal stimulus packages might be different from the reception of news about liquidity assistance programs. The temporal suspension of the restrictions implied by the Stability and Growth Pact (SGP) among euro area countries is likely to affect markets differently from the news about the European Commission stimulus package. We believe that this disaggregation is important to take account of the vast variety of different policy initiatives. Many announcements are coded as a $0 / 1$ dummy variable. If possible, however, we use the size of the program relative to GDP as the explanatory variable. For the asset purchase program of the ECB, which stipulates purchases according to the capital key, announcements are coded as a country's capital key in order to prevent the program having the same magnitude for Estonia and Germany, for example.

Another important contribution is that we differentiate between the first announcement in a series of policy steps and the subsequent announcements. The reason is that the response to the first announcement might be dominated by the revelation of private information through the policy step. For example, a surprise ECB announcement about unconventional policies could be interpreted in terms of an informational advantage of the ECB relative to market participants. If investors update their beliefs about the state of the economy, stock prices could fall rather than increase.

Finally, we include interacting terms in order to account for the heterogeneity across the sample countries. We let policy announcements interact with the growth rate of COVID-19 cases. This allows us to show that countries heavily affected by the disease respond differently from countries with moderate growth rates of cases.

2 See https://www.bsg.ox.ac.uk/research/research-projects/coronavirus-government-responsetracker.

3 See https://supertracker.spi.ox.ac.uk/. 
Our findings can be summarized as follows: First, markets are sensitive to the number of COVID-19 infections. While stock prices are mainly influenced by global COVID-cases, the bond yields depend only on national COVID-cases.

Second, we find that monetary policy is effective in supporting the real economy and easing the pressure on governmental finances. Announcements of asset purchase programs tend to raise stock returns and reduce bond yields. The first in a series of purchase announcements signals private information of the central bank about the state of the economy. Hence, stocks fall after the first announcement but increase after subsequent announcements.

Third, fiscal announcements tend to reduce stock prices. This holds i.e. for fiscal stimulus and liquidity packages. However, the reverse seems to be true with respect to tax-deferrals. Furthermore, we find that the impact of fiscal policy on national stock markets falls in the growth rate of COVID-19 cases. Hence, the transmission to stock markets is weaker for economies, which are relatively more affected by the virus. Across all subsets of polices, it seems that monetary policy is more effective in supporting the stock market than national fiscal policy. Bond yields tend to increase after expansionary fiscal policy announcements. This is mostly driven by liquidity assistance programs. Hence, investors anticipate the implied future strain on government budgets. Once we allow for interaction terms, we find that the effect of domestic fiscal policy is heterogeneous across countries: countries with a low growth rate of COVID-19 cases benefit from fiscal policy in terms of lower bond yields. In contrast, countries most affected by the virus experience an increase in yields.

Fourth, the stimulus package announcement by the European Commission was accompanied by a strong drop in equity prices and an increase in yields. Markets seem disappointed about both the design and the scope of the package. For stock prices, the single most effective measure at the European level is the suspension of the constraints implied by the SGP. Following this announcement, stock prices increase by four percent. The same announcement, however, raises bond yields in the subset euro area countries as markets anticipate the drop in fiscal discipline.

Fifth, we find that monetary announcements that occur simultaneously to fiscal announcements are particularly powerful in boosting stock prices and reducing bond yields. Moreover, expansionary announcements of national fiscal policy that coincide with announcements of fiscal policy at the European level are particularly effective.

Lastly, we show that a policy announced in one European economy also has spillover effects on asset prices in other countries. This result supports the coordination of policies.

Our analysis is closely related to a small number of other recent studies on the financial market impact of COVID-19. Baker et al. (2020) construct an index of 
newspaper reporting on infectious diseases that covers not just COVID-19, but also previous episodes such as the SARS epidemic. The index has a strong effect on U.S. stock markets, but only since February 2020. Previous diseases, in contrast, left equity markets unaffected. Alfaro et al. (2020) study the sensitivity of the U.S. equity market to the Corona crisis, but also to other crises such as the SARS pandemic. They show that the number of infections has forecasting power for stock returns. ${ }^{4}$

In the early stage of the pandemic, firms should have been more affected if they were more exposed to the global economy, in particular to China. Ramelli and Wagner (2020) use U.S. data and show that stock prices are indeed more sensitive to news about the spread of the pandemic when global exposure is high.

Ettmeier et al. (2020) study the impact of the pandemic on corporate bond yields in the main European economies. They estimate a term structure model to obtain corporate bond yields for different maturities. The spread of COVID-19 is shown to affect long-term rates, implying that the economic consequences are considered long-lasting. Policy interventions reduce firms' refinancing conditions if they are coordinated across governments or when there is coordination between monetary and fiscal policy.

The fiscal burden associated with fighting the pandemic led to a widening of sovereign spreads in the euro area. Delatte and Guillaume (2020) show that policy announcements of ECB as a response to the pandemic narrowed these spreads significantly.

The paper most closely related to our contribution is Heyden and Heyden (2021). The authors study the response of stock prices in Europe and the U.S. to news about Corona deaths and monetary and fiscal policy measures. They find that stock prices fall on the day the first COVID-19 victim is in the news. Monetary policy contributes to an increase in stock prices, while fiscal policy tends to lower prices. It should be stressed that for each country the authors use the first policy measure only. Many countries, however, implemented a series of monetary and fiscal support steps ranging from liquidity support over stimulus measures in terms of asset purchases or interest rate cuts to the introduction of short-term work. Some of these measures might be more effective than others, which is why we employ a set of disaggregated policy indicators. In addition, the very first policy step could be considered a signal of how bad the situation is, while the subsequent policy steps are more likely to be effective in stabilizing the economy. For this purpose, we use the entire sequence of policies adopted in order to gauge the market responses.

4 Other studies on the impact of the COVID-19 pandemic on stock market returns and volatility, respectively, are Albulescu (2020), Ashraf (2020a, 2020b), Corbet et al. (2021), Lyócsa et al. (2020) and Zaremba et al. (2020). 
Furthermore, the analysis in Heyden and Heyden (2021) does not include supranational policy packages, which are important for member countries of the European Union or the euro area, respectively.

The remainder of the paper is organized as follows: Section two explains the data set. Section three introduces the panel model, while the results are discussed in Section four. Section five sheds light on the robustness of our findings while sections six provides concluding remarks and policy implications. An Online Appendix contains additional results.

\section{Data}

In this section, we introduce the large data set that is the basis for our empirical analysis.

The sample period is February 17, 2020 to April 24, 2020 and the data frequency is daily for a five-day week (Monday to Friday). We include 29 countries, 26 member countries of the European Union plus the United Kingdom, Norway and Switzerland. We dropped Cyprus for reasons of data availability. Hence, the sample countries are Belgium, Germany, Estonia, Ireland, Greece, Spain, France, Italy, Lithuania, Latvia, Luxembourg, Malta, Netherlands, Austria, Portugal, Slovenia, Slovakia, Finland, Denmark, Sweden, Poland, Czech Republic, Hungary, Croatia, Bulgaria, Romania, Norway, Switzerland and the UK.

As the dependent variable, we use either stock prices, bond yields or OIS rates. For each country, we obtain the leading national stock price index and the yield on 10-year government bonds. The daily change in the stock price index (in percent) and the bond yield (in percentage points) is used in the estimations. All series are drawn from Thomson Reuters. Figure 1 shows the normalized levels of stock prices and 10-year bond yields. We see that stock prices drop sharply beginning in midMarch. The response of bond yields, however, is much more heterogeneous across countries. Figure 2 shows the cross-sectional standard deviations of stock market returns and yield changes. The graph shows a large variation of both variables across countries, most notably when the virus hit most European economies in March. In alternative specifications, in particular in the appendix, we use changes in 10-year OIS rates as the dependent variable.

As independent variables we make use of different categories:

First, to estimate the impact of COVID-19, we use the log-differences of the confirmed COVID cases in line with Alfaro et al. (2020). The difference used is always between days $t-1$ and $t-2$ because these are the confirmed COVID cases in real time and, thus, form the basis for decisions on the financial markets. Our dependent variables consist of daily data on weekdays only. Given that COVID 

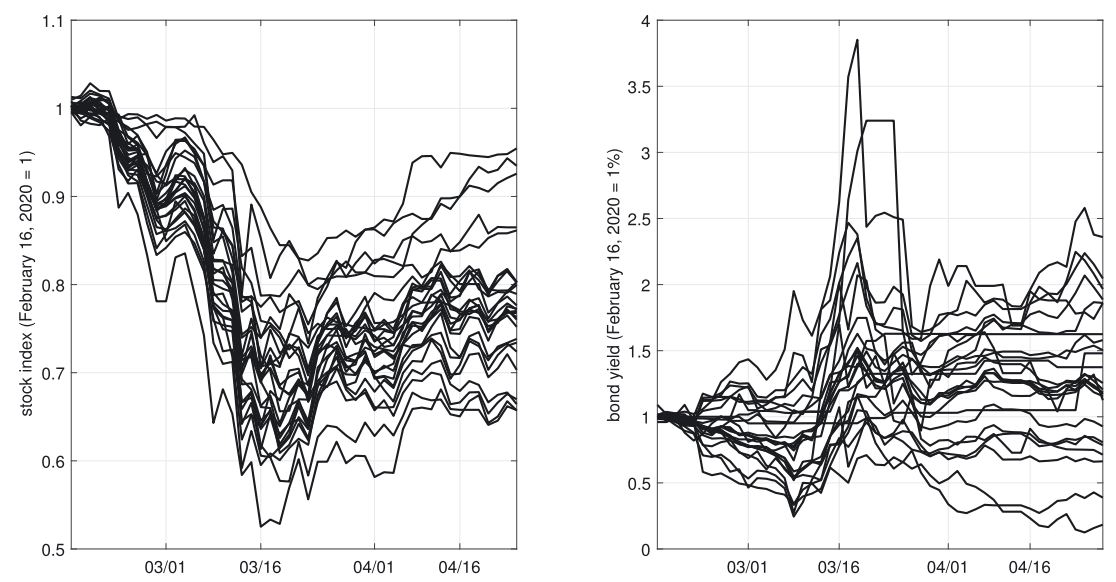

Figure 1: Stock prices and bond yields.

The figure shows the normalized stock prices indices and 10-year bond yields since February 17, 2020.
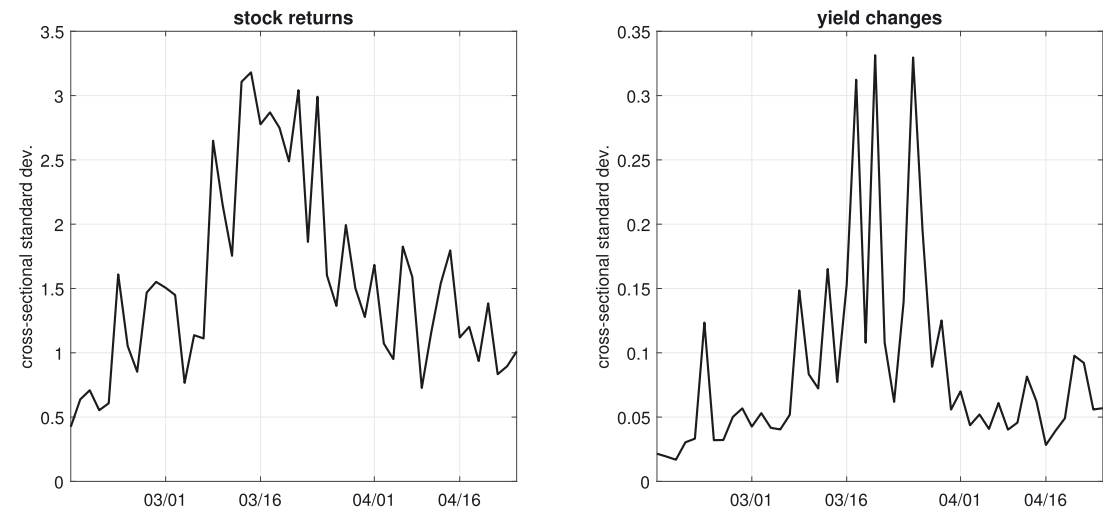

Figure 2: Cross-sectional variation of stock returns and yield changes.

The figure shows the cross-sectional standard deviation of stock returns (in percent) and yield changes (in percentage points) since February 17, 2020.

cases also increase on weekends though, we decide to use the average logdifference over those three days as the measure between Friday and Monday. This is even more justified as in some countries testing and reporting of COVID cases is substantially lower on weekends while the omitted cases are normally added to the 
reports on Monday. ${ }^{5}$ Moreover, we also us the very same method with respect to the number of COVID deaths. However, this regressor performed poorly in the estimation, possibly because it does not contain any new information. This is because it is informative about the number of COVID-19 cases lagged two weeks. ${ }^{6}$ For the number of Corona cases in each country, we use the series of confirmed cases from the Oxford-based Coronavirus Government Response Tracker ${ }^{7}$ and add data of confirmed cases from https://www.worldometers.info/coronavirus/ to fill the remaining gaps. In general, both data sources provide rather similar results. With those data, we compute two different measures of COVID cases. First, the logdifference of the COVID cases in the respective country, COVID-Cases, and, second, the log-difference in COVID cases in the rest of the world, COVID-Cases-World, which are computed as the difference between the confirmed cases in the world minus the cases in the respective country. Besides the log-difference, we add another variable which is the first difference of the log-difference. This measure gives an indication whether "flattening the curve" of COVID growth cases has an impact on financial variables.

Second, we identify policy events in three different categories: monetary events, national fiscal events and European fiscal events. Our first empirical strategy is to use dummy variables taking a value of one for every announcement date and zero otherwise. ${ }^{8}$ The date and the nature of the each announcement are taken from the website of central banks as well as national and European fiscal authorities and in a few cases from other sources like national newspapers. We correct for the time of the announcement. When an announcement was made after markets closed, we assign the event dummy to the next trading day. One example is the ECB's announcement of the PEPP, which was made on March 18 close to midnight. The announcement could not have influenced stock prices and bond yields before March 19. It should be noted that all policy measures appear to be expansionary, irrespectively of the category chosen. The only exception may be the interest rate hike in the deposit rate from $-0.25 \%$ to $-0.1 \%$ by Danmarks National bank on March 19. However, this measure was introduced with additional refinancing operations, which should have a larger effect. Hence, we do not need to

5 However, in a robustness check we also use weekly changes in COVID-cases in order to circumvent the possible weekend effects. The results remain broadly unchanged and can be found in the Online Appendix.

6 Of course, this does not mean that all confirmed COVID cases lead to deaths within a two week period, but rather that the trends are similar.

7 See https://www.bsg.ox.ac.uk/research/research-projects/coronavirus-government-responsetracker.

8 See Benmelech and Tzur-Ilan (2020) for an analysis of the determinants of the choice of policies across 35 advanced and 50 emerging economies. 
distinguish between positive and negative announcements. Moreover, for all three event groups we add an interaction term with the growth rate of COVID-19 cases, checking whether the effectiveness of policy measures varies with the extent to which the countries are faced with the pandemic.

In addition to this broad categorization, we disentangle the events in each category into different groups: for the Monetary-Events, we built four subcategories, which are Additional, Purchases, Rate and Refinancing. Additional accounts for any monetary policy announcement made which does not belong to the other three subcategories. Typical examples in this respect are the easing of collateral constraints or a reduction in required reserves by central banks. Since the details of those announcements vary widely, they are implemented as 0/1 dummies. Purchases cover all announcements concerning the introduction or expansion of purchase programs. Since those programs are typically announced by referencing to the size of the program, we compute this variable as the effective economic impact, which is the size of the program relative to real GDP in 2019. This is in line with calculations of fiscal events by Bruegel. ${ }^{9}$ Note that purchase programs announced by the ECB are assumed to be equally distributed among the euro area countries based on the capital key of the ECB. This is what is announced for the expansion of the Public Sector Purchase Programme (PSPP) and the introduction of the PEPP. Since Greek bonds are not bought under the PSPP, the respective enlargement of this program is not included as an event for Greece.

Rate covers all key interest rate changes by central banks. This measure is introduced as the change of interest rates in percentage points. Refinancing covers all announcements of additional refinancing operations by central banks. Since the actual take-up of funds is unknown at the time of the announcement, this variable is constructed as a 0/1 dummy.

(National) fiscal events, Fiscal-Events, are also divided into four subcategories: Deferrals, Impulse, Liquidity and Shorttime. Deferrals contain mainly tax-postponements in order to temporarily reduce the tax-burden of companies or households. Since the actual use of those deferrals is ultimately determined by the private sector, this variable is introduced as a 0/1 dummy. Impulse measures all economic stimulus given by governments. These can broadly take the form of either tax reductions or increased government expenditures. Since the size of those programs is generally well communicated by the governments, we use the size relative to GDP in 2019. Liquidity is measured by credit or guarantees to the private sector given by the fiscal authorities. Thus, it is different from impulses as liquidity support has to be repaid and is temporary. Besides, we also take the size of the measure relative to GDP in 2019. The variable Shorttime indicates whether

9 See https://www.bruegel.org/publications/datasets/covid-national-dataset/. 
the respective country has introduced or expanded some kind of short-term working scheme in the Corona crisis. Since at the time of the announcement the actual demand and, thus, the costs for the scheme are unknown, this variable is introduced as a 0/1 dummy.

The European fiscal events, Fiscal-EU, are subdivided into three categories, namely Impulse, Liquidity and SGP. Impulse and Liquidity are constructed in the same fashion as for the national fiscal events. For the respective contribution of the European events on national levels, we categorize the events as being conducted by the European Union or the Eurogroup. While the prior affects all EU-countries, the latter affects only those being also part of the monetary union. The size of these events is determined by the relative size of a country as given by its share in GDP in 2019. This being said, there are no European events for the three non-EU countries in our sample (Norway, Switzerland and United Kingdom ${ }^{10}$ ). SGP is a 0/1 dummy covering the effect of the announcement of the temporary suspension of the SGP by the European Commission.

Table 1 provides the number of events across countries and across event categories. All in all, we identify 427 events in the various categories. Please note, however, that several events could occur on the same day when governments or central banks announce a package of different measures at the same time. We see that the number of events is relatively equally distributed among countries with a mean of 14, a maximum of 19 and a minimum of nine events. Moreover, with one exception being the interest rate changes by the central bank, we find a sufficient number of events in almost all categories. The exception is due to the fact that the ECB did not change its key interest rate in the sample period.

Figure 3 shows the distribution of the event dates divided into the three broad categories. We see that the events are concentrated in mid to end of March. However, some important European and monetary events also occur in April. Note that the announcements by the European Commission, the Eurogroup or the ECB are recorded as events in several countries in our sample. ${ }^{11}$

Third, in order to account for the reduction in economic activity due to lockdown measures by the government or simply the fear of people getting infected with the Coronavirus when leaving their homes, we use data from the Google Community Mobility Report as a summary statistic that is available at https:// www.google.com/covid19/mobility/. The data, which is using information from

10 We excluded the United Kingdom from this event category as the country officially left the EU on February 1st 2020, thus shortly before our sample period starts. Even though there is a transition period until the end of 2020, the United Kingdom is no longer bound to the new EU-regularities and -announcements made within the COVID pandemic.

11 The dataset is available to interested researchers. 


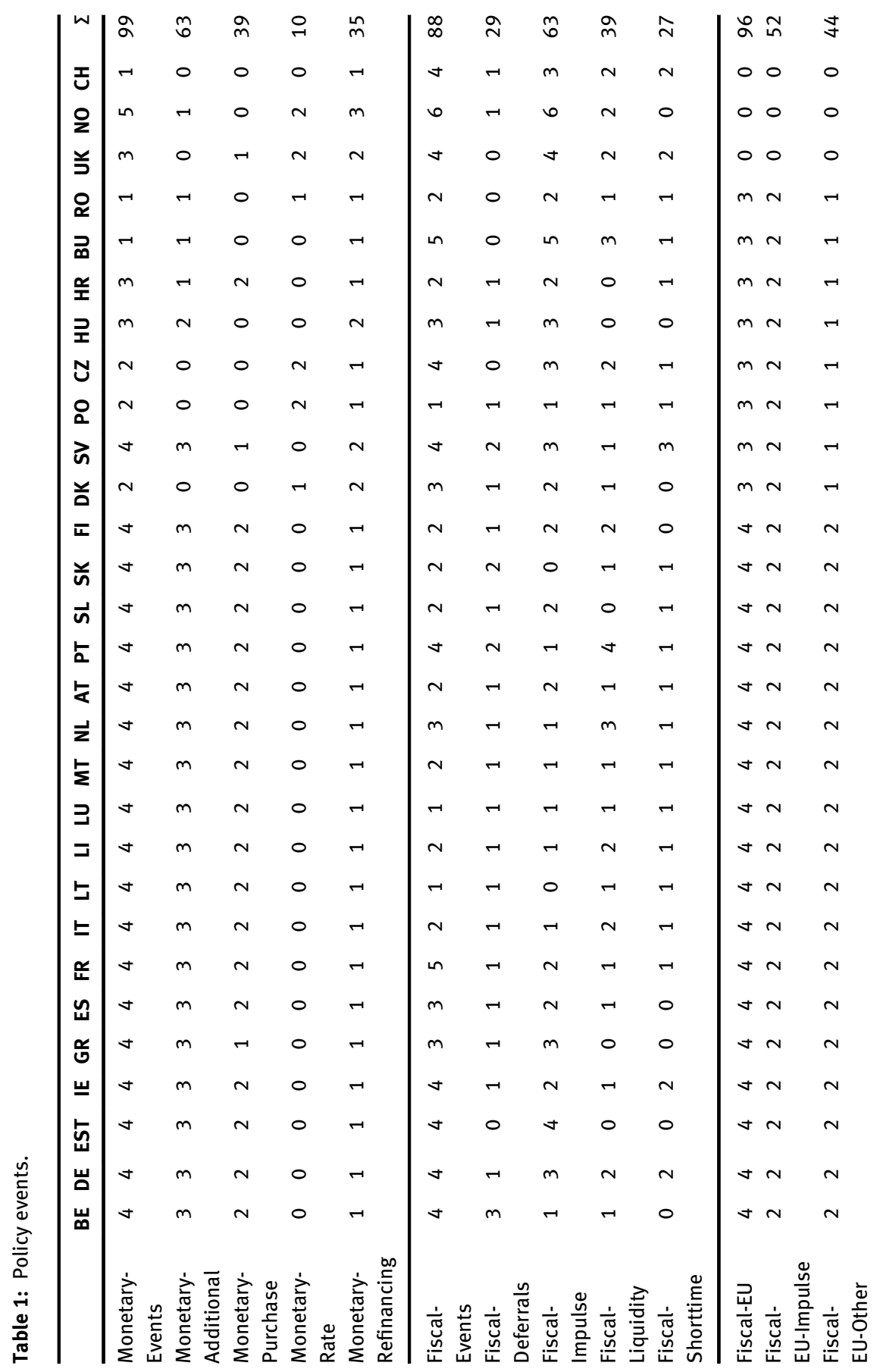




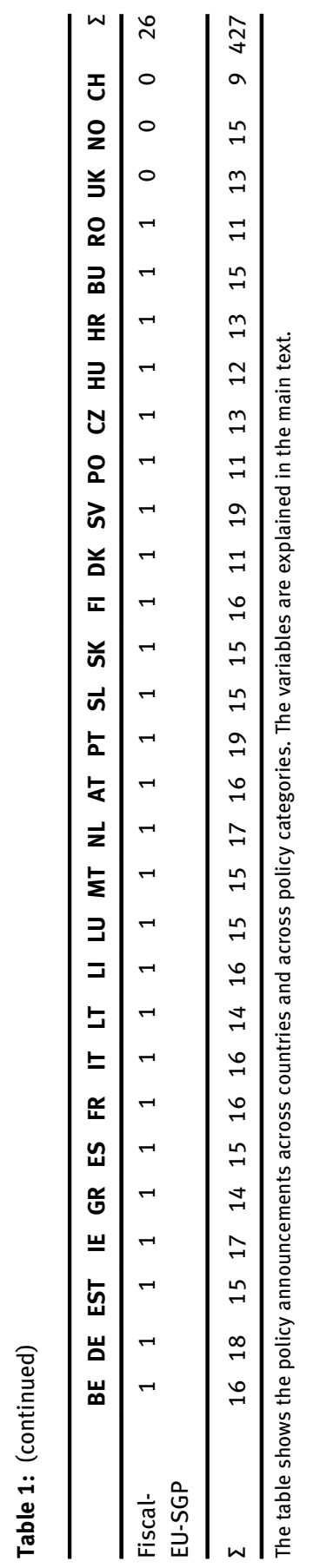




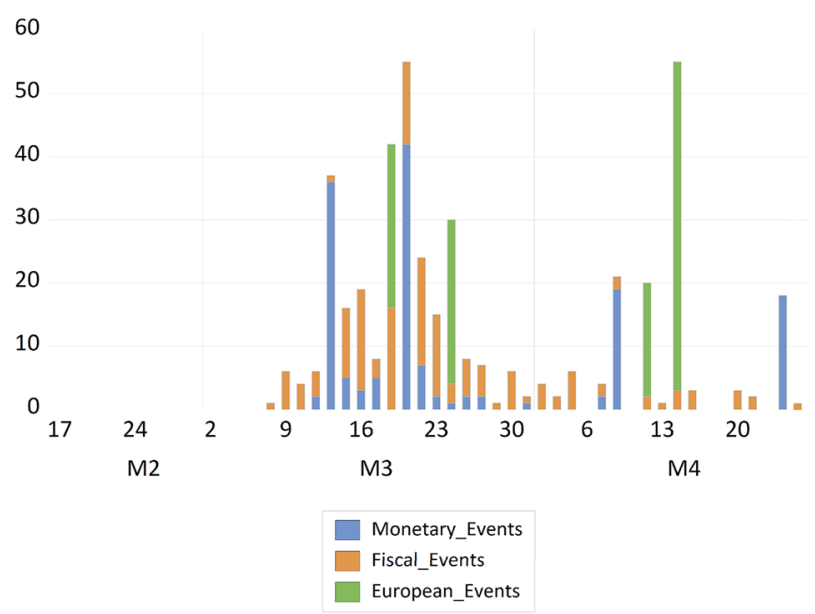

Figure 3: Event dates.

The figure shows the distribution of policy announcements over time. The vertical axis reports the number of policy events. The variables are explained in the main text.

Google products such as Google Maps, reports the reduction in movement trends over time relative to a baseline case, broken down into different fields. In the absence of high-frequency information on the state of the economy, the information on mobility also serves as a proxy for the underlying business cycle. We use the mobility indicators for the following fields: Transit Stations, Workplaces and Residential. ${ }^{12}$ We take the log-differences of the index while the respective value for period $t$ is always the difference between $t-1$ and $t-2$.

Additionally, we also add US-monetary policy events with the very same subcategories as for the monetary events explained above. The reasoning is that global stock markets are frequently influenced by US-monetary policy.

Finally, we added the change in the volatility of the leading stock market indicators. Since this volatility is only available for Germany, France, the Netherlands and Switzerland, we approximate it for the other countries with the VSTOXX. However, it appears that this variable is also driven by the announcements, thus this variable cannot be interpret as being completely exogenous.

12 Three more categories would have been available with Grocery, Parks and Retail. However, we do not believe that those are good indicators to measure economic activity, i.e. that those contain additional information not present in the data of the three categories we use. 


\section{A Panel Model}

We estimate a standard panel model with country fixed effects. The dependent variable, $\Delta y_{t, i}$, is either the percentage change of the leading stock market index (in percent) or the change in the yield on a 10-year government bond (in percentage points) of country $i$ at time $t$. The estimated model is

$$
\Delta y_{t, i}=c_{i}+\boldsymbol{\beta}_{1} \boldsymbol{C}_{\boldsymbol{t}, \boldsymbol{i}}+\boldsymbol{\beta}_{2} \boldsymbol{X}_{t, i}^{\mathrm{mon}}+\boldsymbol{\beta}_{3} \boldsymbol{X}_{\boldsymbol{t}, \boldsymbol{i}}^{\mathrm{fis}}+\boldsymbol{\beta}_{4} \boldsymbol{X}_{\boldsymbol{t}}^{\mathrm{EUfis}}+\boldsymbol{\beta}_{5} \boldsymbol{X}_{\boldsymbol{t}}^{\mathrm{Fed}}+\boldsymbol{\beta}_{6} \boldsymbol{X}_{\boldsymbol{t}, \boldsymbol{i}}^{\text {lock }}+\epsilon_{t, i},
$$

where $c_{i}$ is the country fixed effect. We include six sets of explanatory variables. The vector $\boldsymbol{C}_{\boldsymbol{t}, \boldsymbol{i}}$ captures information on the growth rate of COVID-19 cases, both at home and in the rest of the world. The other vectors collect the policy announcements discussed in the previous section. The first, denoted as $\boldsymbol{X}_{\boldsymbol{t}, \boldsymbol{i}}^{\text {mon }}$, summarizes the announcement of the different monetary policy measures introduced before. Announcements of fiscal policy at the national (European) level are summarized by $\boldsymbol{X}_{t, \boldsymbol{i}}^{\mathrm{fis}}$ $\left(\boldsymbol{X}_{\boldsymbol{t}}^{\mathrm{Eufis}}\right)$. The announcements of the Federal Reserve are included in the vector $\boldsymbol{X}_{\boldsymbol{t}}^{\mathrm{Fed}}$, while the Google Mobility Report data summarizing the effective lockdown is denoted as $\boldsymbol{X}_{\boldsymbol{t}, \boldsymbol{i}}^{\text {lock }}$. In a separate specification, we also include the change in stock market volatility as explained above. The $\boldsymbol{\beta}$ vectors summarize the estimated coefficients. We estimate the model with White cross-sectional standard errors, thus accounting for possible correlations in the cross-sections as well as heteroscedasticity.

Asset markets should respond to the unanticipated component of news only. Some of the policy announcements in our dataset came as a surprise, both with respect to the timing of the announcements and the scope of the scope of the policy measures. For example, the ECB decision to implement the $€ 750$ billion PEPP was announced after an unscheduled meeting of the Governing Council on March 18. However, other announcements have at least partly been anticipated. The implementation of fiscal policy typically follows weeks of public debate, such that markets could form expectations about future policies. Nevertheless, even in this case the exact volume and the duration of the policy measure might come as a surprise. ${ }^{13}$

\section{Results}

We report the results for two dependent variables, namely the daily percentage change in the leading stock price index and the daily change in 10-year bond

13 Of course, we cannot rule out that some details of the program are leaked in advance. VissingJorgensen (2019) shows that details of Federal Reserve decisions actions are leaked to the press before the official announcement. 
yields. ${ }^{14}$ In the Online Appendix, we also provide the responses of Overnight Index Swap rates.

\subsection{The Response of Stock Prices}

Table 2 shows the estimated coefficients for the panel model estimated on stock market data. We report estimates from different specification with a varying degree of granularity of policy measures. We also allow for interaction terms between the three branches of policy, i.e., monetary, domestic fiscal and European fiscal, and the growth rate of COVID-19 cases. Hence, we are interested in whether the effectiveness of policies varies with the extent countries are affected by the Coronavirus. The inclusion of interaction terms allows us to, at least partially, account for the heterogeneity of the responses across the sample countries.

We begin with models without any control variables. Then we show specifications that include information on the growth rate of the domestic and global COVID-19 cases, the Google Mobility indicators and, in the final two columns, information from abroad. The empirical fit strongly increases when we include these control variables. For all models, the estimated coefficient on the growth rate of domestic COVID-cases is not statistically significant. For most models, the global number of cases enters with a positive sign, which is puzzling at first sight. However, the change in the growth rate of the global number of cases has a highly significant negative coefficient, which is large in absolute magnitude. Stock prices fall strongly if the global growth of COVID-19 cases accelerates.

Six estimated models contain the three Google Mobility indicators that summarize the effectiveness of the lockdown measures as mentioned before. The estimated coefficients, however, remain insignificant. A possible reason for this is that the reported number of COVID-19 cases already summarizes the information about the severity of the crisis investors are most sensitive to.

In the first column, we differentiate only between monetary and domestic fiscal events as well as fiscal events at the European level. Neither of the coefficients is statistically different from zero. This finding supports the need to disaggregate the policy measures in order to shed light on subsets of policies.

In the second column, we split monetary, fiscal and European fiscal events into the subcategories introduced in the previous section. Announcements of asset purchases by the central bank do not enter significantly. Only in column VI,

14 See Conrad and Zumbach (2016) for empirical evidence on the effect of speeches from policymakers during the European sovereign debt crisis on stock, bond and foreign exchange markets. 


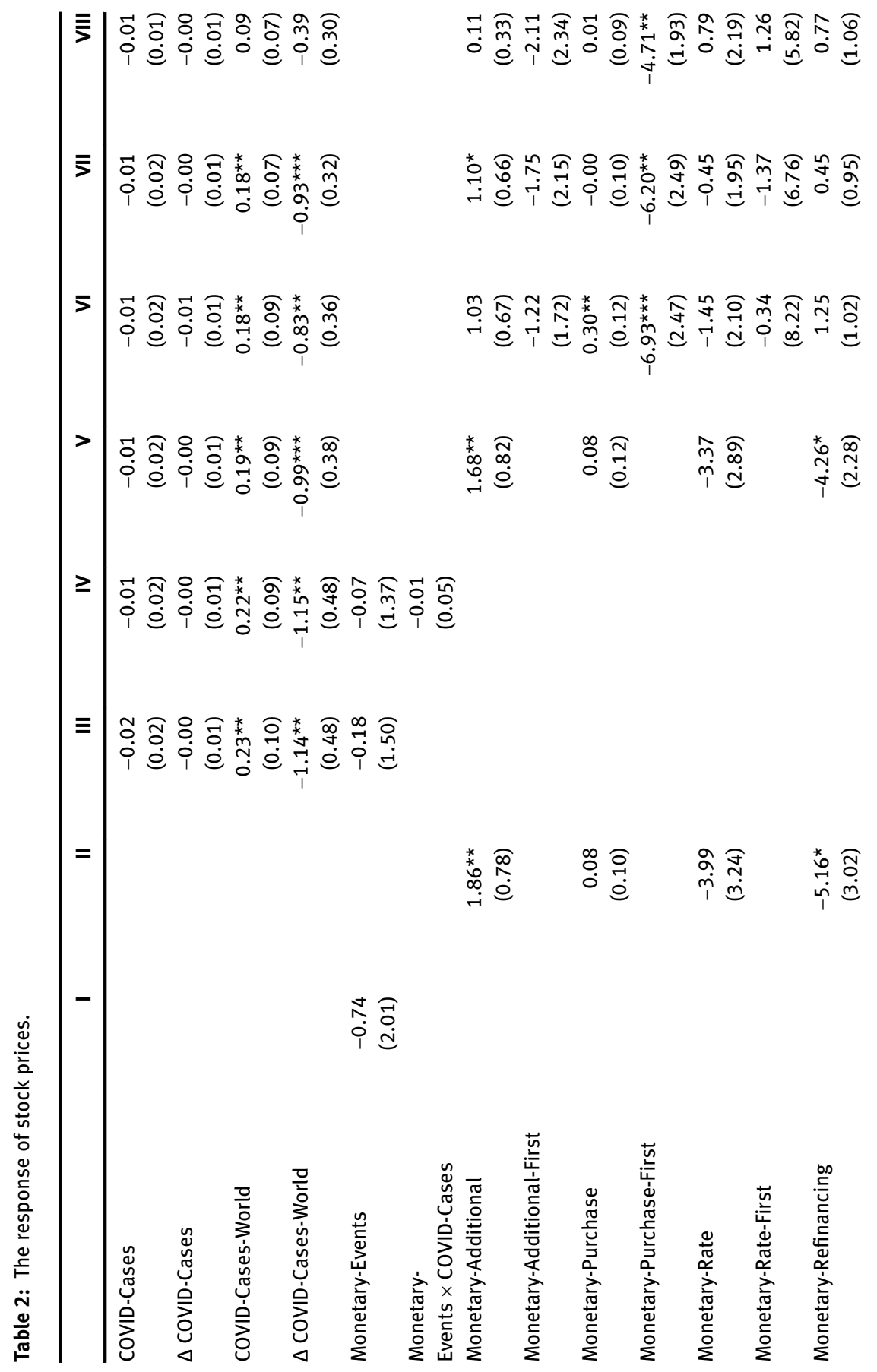




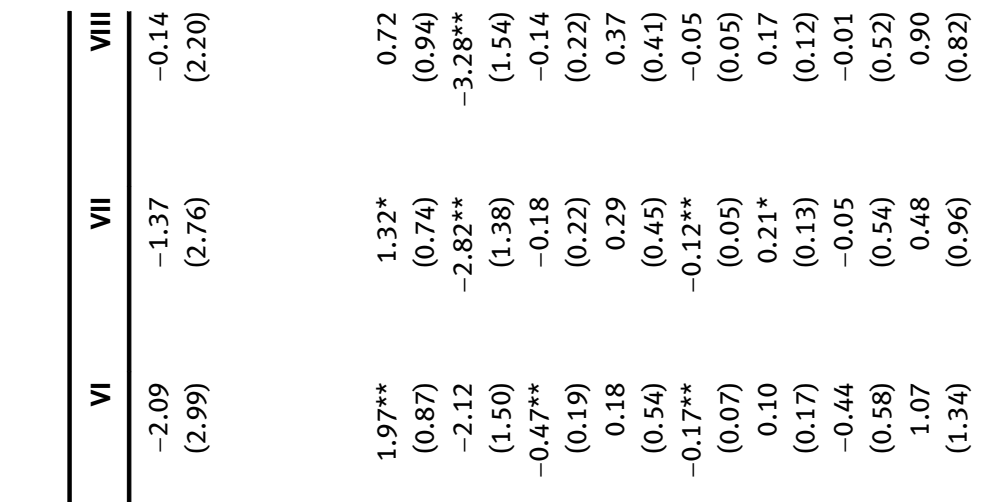

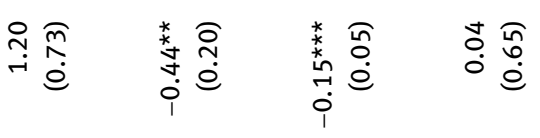

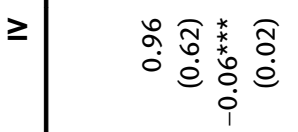

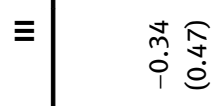

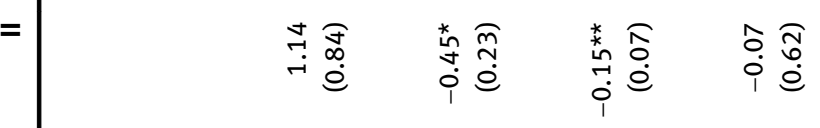

$$
\begin{aligned}
& \text { - } \quad \begin{array}{ll}
0 & 0 \\
m & 0 \\
0 & 0 \\
i & 0
\end{array}
\end{aligned}
$$

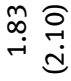

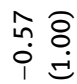

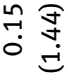

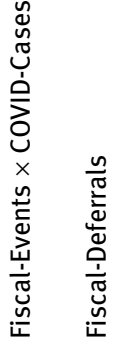

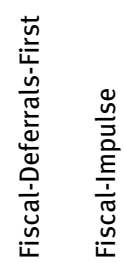

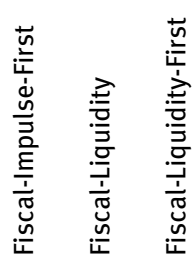

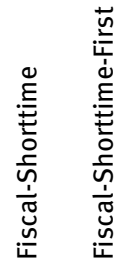

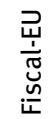




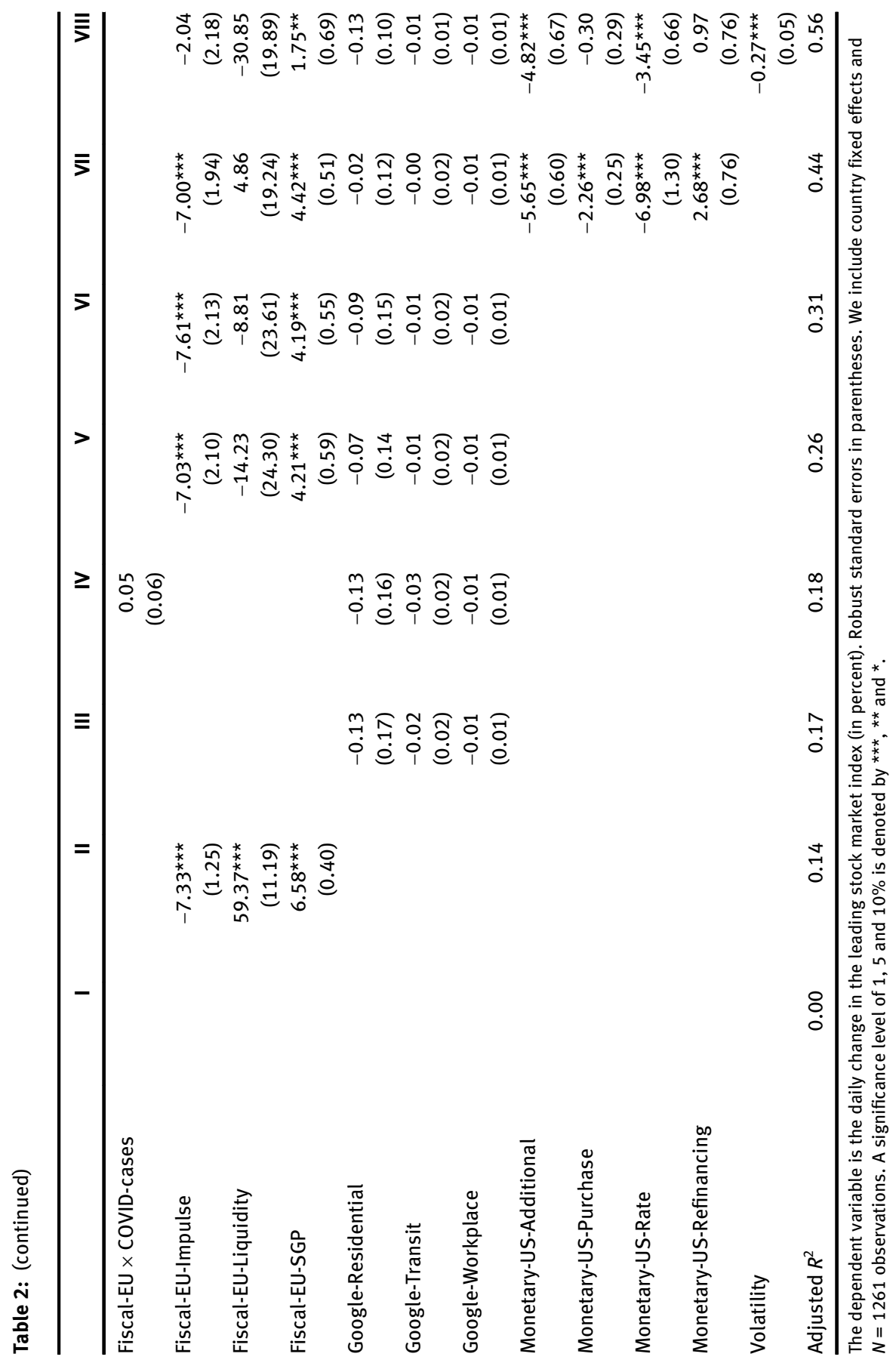


i.e., with additional control variables, we find the expected positive impact on the stock market.

In contrast, other types of policy events, which we summarize by the variable Monetary-Additional, have the expected positive sign. An announcement of a policy initiative in this category raises stock prices by 1.9 percent. Changes in the requirements for refinancing operations have a negative sign, which is counterintuitive. Concerning national fiscal policy, fiscal impulses and liquidity assistance reduce stock prices, while other types of fiscal policy, remain insignificant in this specification even though in the other specifications especially Fiscal-Deferrals tend to increase stock prices. Fiscal stimulus measures at the European level also enter with a large negative sign. The negative sign could reflect the fact that markets were disappointed by the design or the volume of the fiscal impulses. This is also consistent with the response of bond yield changes presented below, which increase by $0.4 \mathrm{pp}$ when the European stimulus measures were announced. Stock prices are also sensitive to the announcement that the European Commission suspends the SGP. Upon this announcement, stock prices increase by more than six percent. Market participants were clearly focused on the constraints imposed by the SGP, such that a relaxation of these constraints boosts equity markets.

The coefficient on liquidity measures at the European level is significantly positive, which is in line with our prior. The magnitude of the coefficient, however, is counterintuitive. Since the coefficient becomes insignificant once we add additional control variables, we treat the size of the coefficient as an artifact of the empirical specification. Across all empirical specifications in this table and most other tables in the remainder of the paper, EU-level fiscal impulses and the relaxation of the suspension of the SGP remain highlight significant drivers of asset prices.

In column IV, we include the aggregate policy categories and add control variables. The results remain insignificant, which again highlights the importance of a disaggregated look at different policies. With interaction terms between policies and the number of COVID-cases, see column IV, broadly defined fiscal events enter positively, though the coefficient remains insignificant. A larger growth rate of COVID-19 cases, however, reduces the effectiveness of fiscal policy. Hence, fiscal policy was most supportive for member countries with a relatively low growth rate of Corona cases.

The estimates reported in column $\mathrm{V}$ are largely similar to the model shown in column III. Fiscal policy other than the suspension of the SGP leads to a fall in stock prices.

An announcement of a drastic policy step, either monetary or fiscal, could also be interpreted as a signal about the state of the economy. Suppose markets are incompletely informed about the true state of the economy. A drastic rate cut by the central bank could reveal private information of the central bank suggesting that 
the situation is worse than expected. Jarocinski and Karadi (2020) introduced this notion of information shocks into the literature. If the information component of an expansionary announcement dominates the policy component, the effect could become negative such that stock prices fall. Note that the information advantage of the central bank stems from its preferential access to incoming data, not necessarily from its superior ability to predict the consequences of the pandemic. Hence, we believe that the central bank's information advantage prevails even in the uncharted territory of a global pandemic.

In the panel framework, we cannot differentiate between information shocks and policy surprises. ${ }^{15}$ Instead, we differentiate between the first announcement of each policy type and the subsequent announcements. This captures the notion that the first fiscal or monetary measure is likely to be dominated by the information component. Hence, if the sign of the coefficient on the first step is different from the sign of the coefficient on the subsequent measures, information shocks could be important.

The sixth column reports the extended model which accounts for information effects. We find that the information shock matters for announcements of asset purchases by the central bank. The initial announcement has a strongly negative impact on the stock market, suggesting that investors updated their information set and adjusted to the negative news about the economic situation. Subsequent announcements have the expected positive sign. For most other measures, the distinction between the first and the remaining measures does not seem to play an important role.

Column VII of the table reports estimates for a model that is augmented by announcements of the U.S. Federal Reserve (Fed). The first three categories of U.S. monetary policy enter with a negative and significant coefficient. Hence, European stock prices fall when the Fed cuts the Federal funds rate. Only the fourth category, Monetary-US-Refinancing, enters with the expected positive sign. One explanation of this counter-intuitive finding is that information effects, similar to the effects described before, change the sign of the coefficients. If the Fed decision reflects a deterioration of economic activity in the U.S., stocks in Europe should fall. All other coefficients remain broadly unchanged when U.S. policy responses are included.

In the model reported in the last column, we add the implied stock market volatility as a control variable to capture the fact that many policies were announced in times of market turbulence. While volatility itself enters with a positive coefficient, it does not change the results compared to column VII.

15 The drop in stock prices is in line with D'Orazio and Dirks (2020), who show a negative effect of COVID-motivated ECB announcements on the stock market. 


\subsection{The Response of Bond Yields}

We now turn to the results for the change in 10-year bond yields as the dependent variable. Table 3 reports all estimated coefficients. An increase in the number of COVID-19 cases raises bond yields, suggesting that investors anticipate future fiscal burdens associated with the pandemic. The change in the growth rate of cases, however, has a negative coefficient. An acceleration of the growth of Corona cases reduces yields, probably reflecting that fiscal rescue packages become more likely if the spread of the virus gains momentum.

Among the different monetary events, it is predominantly the announcement of asset purchases that contributes to lower long-term interest rates. ${ }^{16}$ This effect remains highly significant across all model specifications. The first announcements of purchases, however, had the opposite effect as the central bank action revealed information about the deterioration of economic activity.

Announcements of national fiscal policy as such remain insignificant, though the interaction with the number of COVID-cases is significantly positive. The larger the number of cases, the more a fiscal expansion raises bond yields. Before the outbreak of COVID-19, several countries suffered from elevated levels of government debt. The consequences of the drop in economic activity and the fiscal support packages contribute to the rising debt burden. Investors charge higher interest in order to be willing to hold long-term government bonds. We also see that the increase in borrowing costs of governments is driven by countries which are strongly affected by the virus. This is because once we allow for an interaction between national fiscal policy and the growth rate of COVID-19 cases, the coefficient on the interaction term is significantly positive, while fiscal policy as such is not significant. This is mostly driven by the announcements of national liquidity assistance programs. The results are consistent with the view that investors predominantly see the fiscal burden rather than the stimulating impact on the economy as the main consequence of the expansionary fiscal policy steps.

The announcement of the European stimulus package contributes to higher sovereign bond yields. The coefficient on Fiscal-EU-Impulse is positive and highly significant. Markets seem to be aware of the long-term budgetary consequences of stimulus announcements, such that interest rates increase. This coefficient is significantly positive across all model specifications. We find again that announcements of the Fed enter with an unexpected sign. When the Fed announced the

16 The impact of asset purchases is consistent with the findings of Hartley and Rebucci (2020), who show that the average QE announcement across advanced economies reduces yields by $-0.14 \%$ points. 


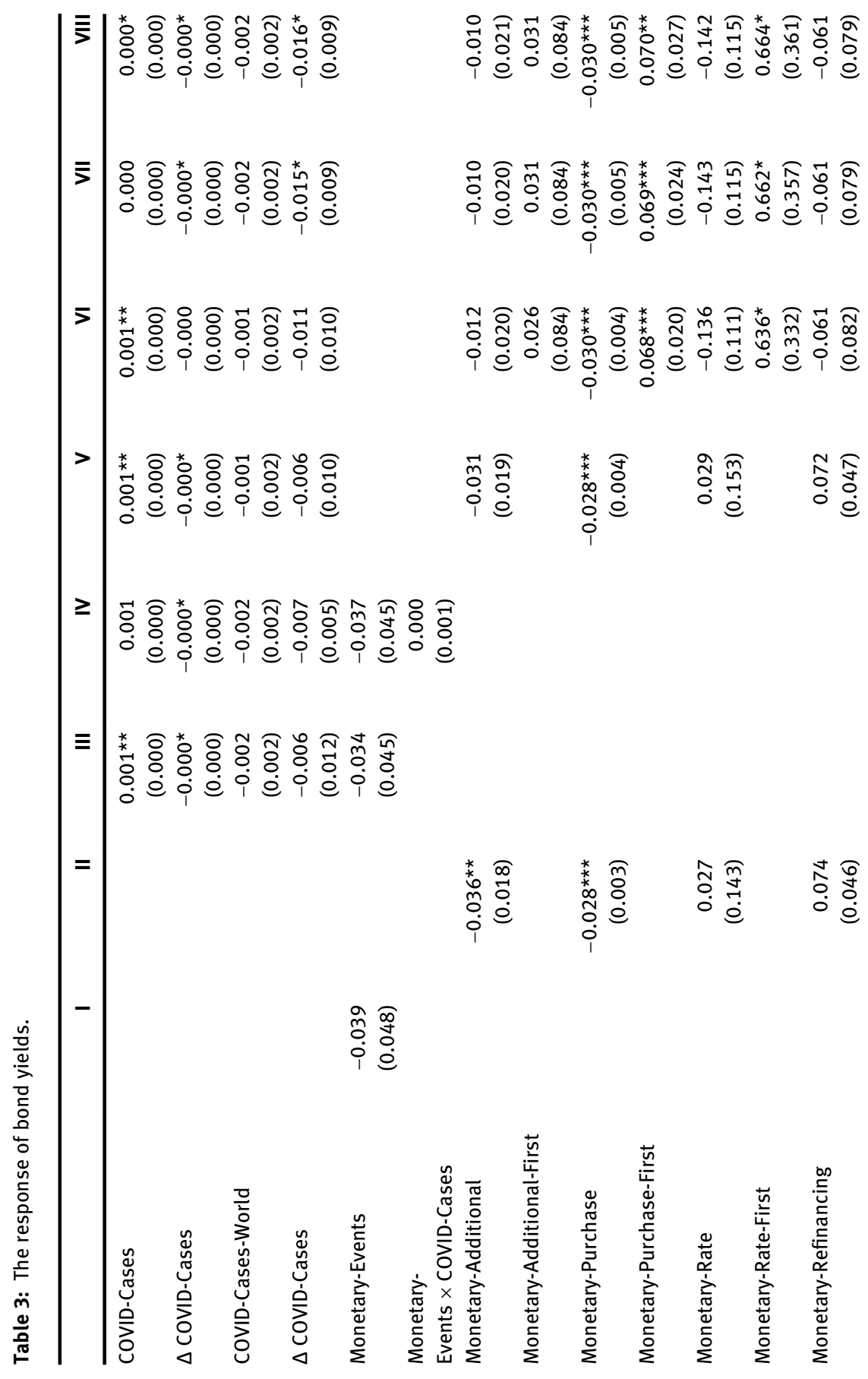




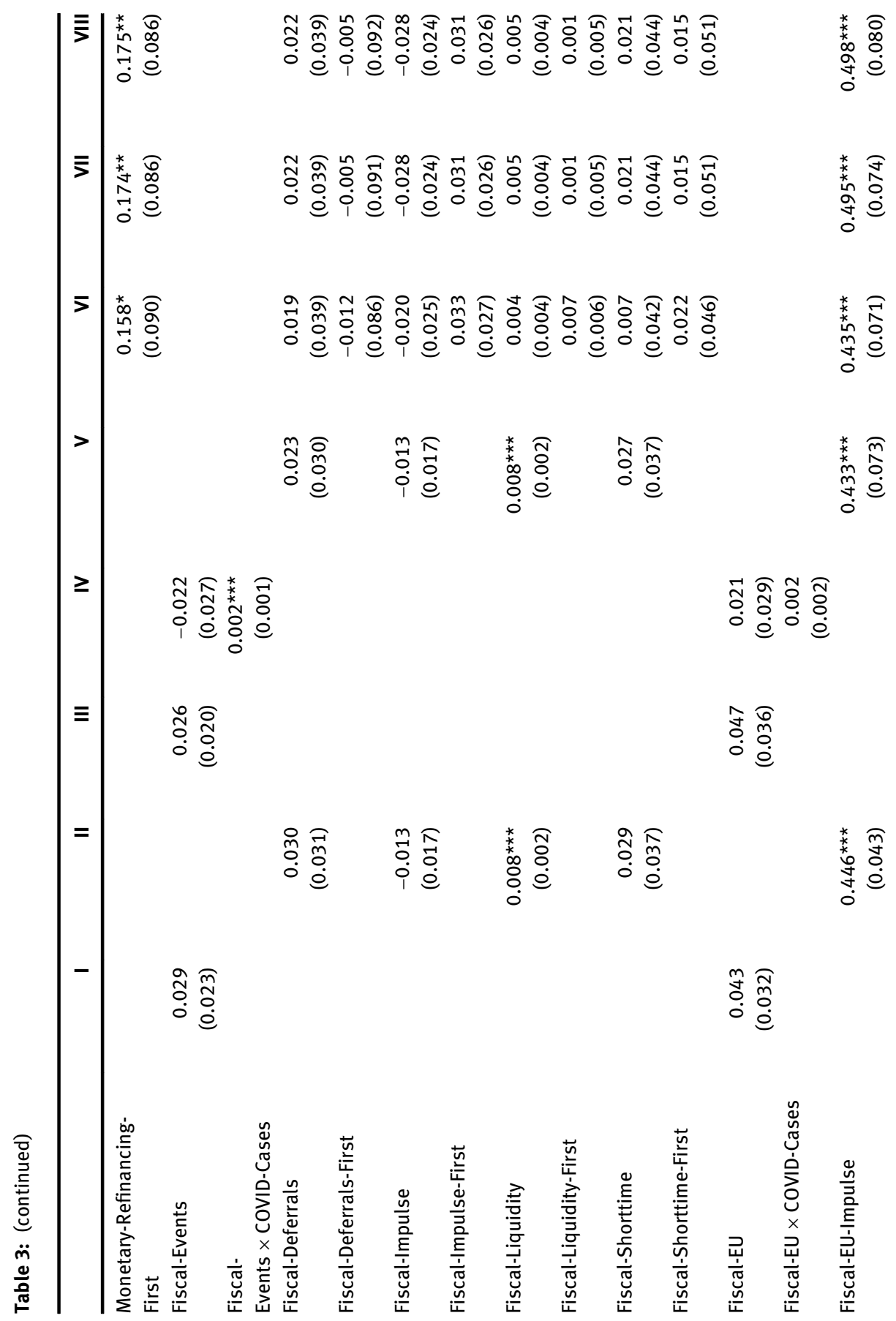




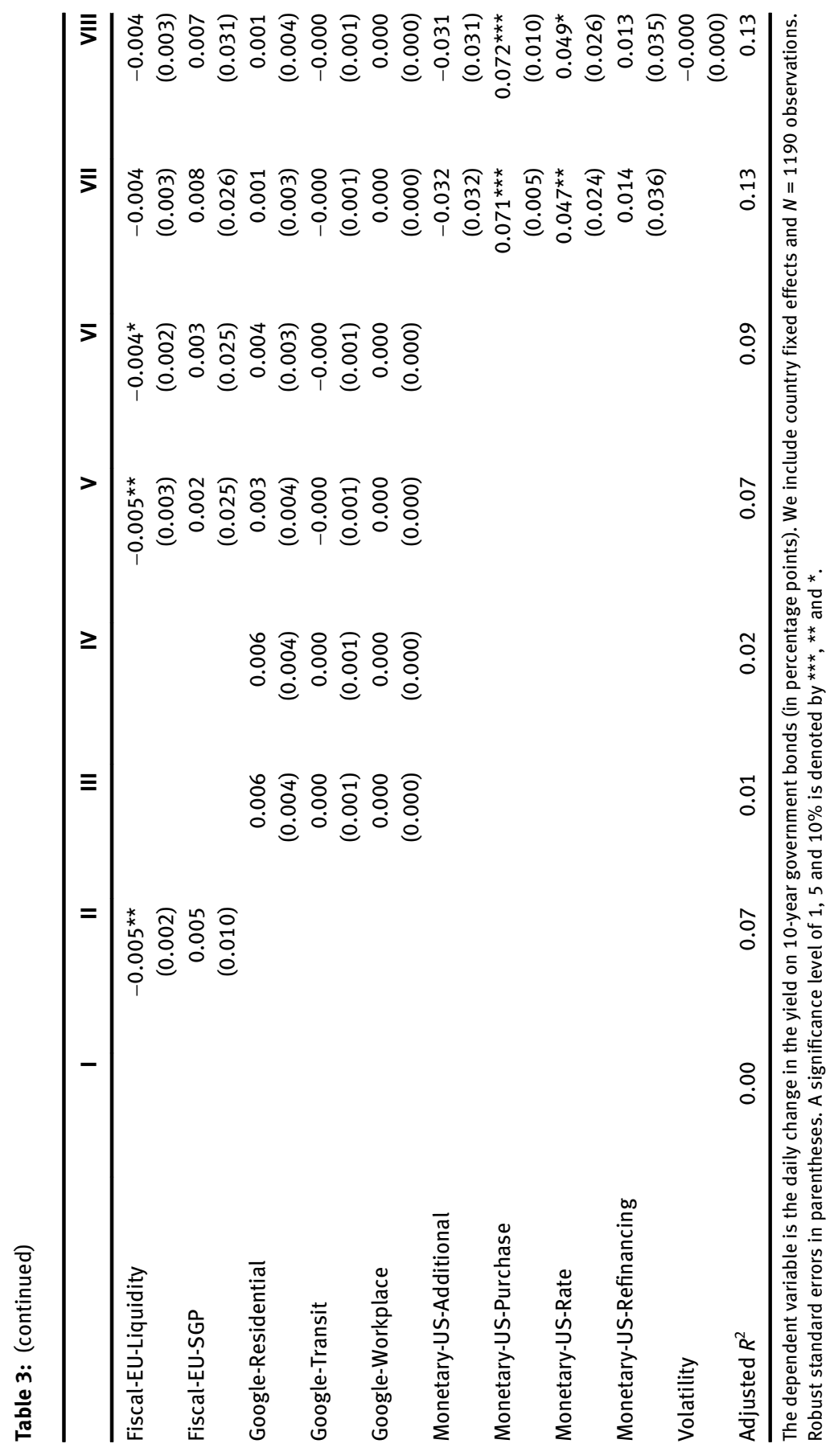


purchase of assets, European bond yields rise. All lockdown variables remain insignificant.

Taken together, the results suggest that purchase programs of the central bank are the single most effective instrument during the Corona pandemic. These announcements tends to raise stock prices and reduce bond yields. Fiscal stimulus and liquidity measures, in contrast, reduce stock price and raise interest rates. The same holds with respect to fiscal impulses conducted at a European level. The reason could be that investors (i) were disappointed by the size of the fiscal policy responses or (ii) discount future refinancing needs of European governments. Interestingly, the suspension of the SGP has a strong effect on stock market valuations, but leaves bond yields unaffected.

\subsection{Simultaneous Events}

We now turn to the issue of simultaneous policy events in two of our broad categories. ${ }^{17}$ We do so for our overall sample, but also for a sample including only Euroarea countries and one with one large countries. The countries included in both sub-samples is explained in detail in our robustness checks. In order to identify simultaneous events, we interact the monetary, fiscal and European events with each other. We end up with three interaction terms, Monetary-Events $\times$ FiscalEvents, Monetary-Events $\times$ Fiscal-EU and Fiscal-Events $\times$ Fiscal-EU. For each of the three pairs, there are 14, 1 and 10 events, respectively, which occur simultaneously for our sample including all 29 countries. ${ }^{18}$

Table 4 presents the results for stock market returns, government bond yields and the three different selections of sample countries included. The coefficients on the number COVID-19 cases remain broadly unchanged compared to the results presented in the previous sections. When it comes to the response of stock market returns, it appears that simultaneous events indeed boost stock prices. This holds irrespectively of which two policy areas act jointly. For the full sample joint policy actions raise stock prices by about 1.9 percent to 4.5 percent.

For government bond yields, the response is the mirror image of to the stock market reaction. For monetary-events which take place on the same day with European fiscal events, the yields are substantially lowered, meaning that if European fiscal policies are accommodated by monetary policy, this lowers refinancing costs for governments.

17 Please note that there is not a single day where three events occurred for one country.

18 For the sample including only euro area countries, there is no simultaneous event for Monetary-Events $\times$ Fiscal-EU. Therefore, no estimates can be presented in this case. 
Table 4: The market responses including simultaneous events.

\begin{tabular}{|c|c|c|c|c|c|c|}
\hline \multirow{3}{*}{$\begin{array}{l}\text { Dependent } \\
\text { variable: }\end{array}$} & \multicolumn{2}{|c|}{ all countries } & \multicolumn{2}{|c|}{ euro area } & \multicolumn{2}{|c|}{ large countries } \\
\hline & Stocks & Yield & Stocks & Yield & Stocks & Yield \\
\hline & I & II & III & IV & v & VI \\
\hline \multirow[t]{2}{*}{ COVID-Cases } & -0.016 & $0.001^{\star \star}$ & -0.017 & $0.001^{\star \star}$ & -0.012 & $0.001^{*}$ \\
\hline & $(0.017)$ & $(0.000)$ & $(0.017)$ & $(0.000)$ & $(0.020)$ & $(0.000)$ \\
\hline \multirow[t]{2}{*}{$\Delta$ COVID-Cases } & -0.002 & $-0.000^{\star}$ & -0.007 & -0.000 & -0.002 & -0.000 \\
\hline & $(0.011)$ & $(0.000)$ & $(0.012)$ & $(0.000)$ & $(0.012)$ & $(0.000)$ \\
\hline COVID-Cases- & $0.233^{* \star}$ & -0.002 & $0.249^{* *}$ & -0.003 & $0.264^{\star \star *}$ & -0.002 \\
\hline World & $(0.096)$ & $(0.002)$ & $(0.099)$ & $(0.003)$ & $(0.110)$ & $(0.002)$ \\
\hline \multirow[t]{2}{*}{$\Delta$ COVID-Cases } & $-1.132^{\star \star}$ & -0.008 & $-1.050^{\star \star}$ & -0.014 & $-1.276^{\star \star}$ & -0.008 \\
\hline & $(0.475)$ & $(0.011)$ & $(0.455)$ & $(0.014)$ & $(0.549)$ & $(0.014)$ \\
\hline \multirow[t]{2}{*}{ Monetary-Events } & -0.552 & -0.014 & -0.890 & -0.005 & -0.325 & -0.021 \\
\hline & (1.579) & $(0.037)$ & $(2.13)$ & $(0.045)$ & $(1.752)$ & $(0.048)$ \\
\hline \multirow[t]{2}{*}{ Fiscal-Events } & $-0.930^{\star \star}$ & $0.034^{*}$ & -1.064 & 0.041 & -1.033 & $0.043^{\star *}$ \\
\hline & $(0.467)$ & $(0.018)$ & $(0.774)$ & $(0.027)$ & $(0.666)$ & $(0.021)$ \\
\hline \multirow[t]{2}{*}{ Fiscal-EU } & -0.133 & 0.051 & -0.092 & 0.040 & -0.036 & 0.057 \\
\hline & (1.339) & $(0.032)$ & $(1.282)$ & $(0.034)$ & (1.933) & $(0.038)$ \\
\hline Monetary-Even- & $2.491^{\star \star}$ & -0.082 & 2.325 & -0.279 & $2.317^{\star}$ & -0.082 \\
\hline ts*Fiscal-Events & (1.173) & $(0.086)$ & (1.718) & $(0.218)$ & (1.312) & $(0.083)$ \\
\hline Monetary-Even- & $4.504^{\star \star}$ & $-0.577^{\star \star \star}$ & & & 3.633 & $-0.578^{\star \star \star}$ \\
\hline ts*Fiscal-EU & $(1.960)$ & $(0.050)$ & & & (2.567) & $(0.060)$ \\
\hline Fiscal-Even- & $1.874^{\star}$ & 0.013 & 1.736 & 0.041 & 1.749 & -0.010 \\
\hline ts*Fiscal-EU & (1.104) & $(0.033)$ & $(1.995)$ & $(0.044)$ & $(1.215)$ & $(0.033)$ \\
\hline Google- & -0.131 & 0.007 & -0.225 & 0.006 & -0.046 & $0.009^{\star}$ \\
\hline Residential & $(0.164)$ & $(0.004)$ & $(0.161)$ & $(0.006)$ & $(0.218)$ & $(0.005)$ \\
\hline \multirow{2}{*}{ Google-Transit } & -0.025 & 0.000 & -0.035 & -0.000 & -0.020 & 0.000 \\
\hline & $(0.020)$ & $(0.001)$ & $(0.022)$ & $(0.001)$ & $(0.026)$ & $(0.001)$ \\
\hline Google- & -0.007 & 0.000 & -0.008 & 0.000 & -0.008 & 0.000 \\
\hline Workplace & $(0.013)$ & $(0.000)$ & $(0.013)$ & $(0.000)$ & $(0.016)$ & $(0.000)$ \\
\hline Adjusted $R^{2}$ & 0.17 & 0.03 & 0.18 & 0.06 & 0.18 & 0.03 \\
\hline$N$ & 1262 & 1190 & 765 & 691 & 902 & 924 \\
\hline
\end{tabular}

The dependent variable is the daily change in the leading stock market index (in percent) or the yield on 10-year government bonds (in percentage points). We include country fixed effects.Robust standard errors in parentheses. A significance level of 1,5 and $10 \%$ is denoted by ***, ** and *.

Taken together, the results suggest that announcements of different branches of policy on the same are indeed mutually reinforcing the market responses.

\subsection{Cross-border Effects}

European economies are closely connected through trade and financial linkages. Hence, a stimulus measure announced in one economy can have cross-border 
effects on other countries. In this section, we investigate the empirical relevance of spillover effects for our set of policy announcements. For each country $i$, we construct a weighted average of the announcement dummies and the control variables in all other European economies $j \neq i$. The weights correspond to the share of exports of country $i$ to the other economies in 2019. Hence, our weighting scheme rests on the assumption that policies spill-over through trade in goods and services. We include the weighted announcements of other countries in our regression model besides the domestic effects.

We also allow for spillovers of EU-wide policies. Announcement dummies for EU policies enter each the equation for the non-EU countries and each member country in our estimated panel model. Beyond the direct effect of EU-wide policies, there can also be cross-border effects when a policy benefits a particular country, which in turn affects other economies. As an example, consider the SURE announcement of the short-term work program. The direct effect on countries like Germany is supposedly small as Germany will not directly benefit from this scheme. However, the program reduces unemployment in Italy and Spain, and, as a consequence, has spillover effects on the demand for German exports.

Table 5 reports the results for stock prices, government bond yields and OIS rates. The construction of the latter is documented in the Online Appendix. Among the fiscal policy measures, the announcement of deferrals has the largest crossborder effect. Announcements raise stock prices and bond yields in other countries. Fiscal stimulus measures, in contrast, reduce stock price abroad. Spillovers from EU-level liquidity support and the suspension of the SGP lead to higher stock prices, while sovereign yields increase as a consequence of EU-fiscal stimulus programs spilling over across borders.

\section{Robustness}

\subsection{Subsamples}

We now present results for subsets of countries. The first subset of countries is the group of member countries of the euro area. The second subset is restricted to relatively large countries irrespective of their membership to the euro area or EU. Dropping smaller countries of the sample, for instance the Baltic countries, raises the liquidity of the average sample country and narrows the analysis to countries with better data availability. As a cut-off value, we use a level of GDP in 2019 of more than 100 billion euro. Thus, we end up with 20 countries in this subset being Belgium, Germany, Ireland, Greece, Spain, France, Italy, Netherlands, Austria, Portugal, 
Table 5: The market responses including cross-border effects.

\begin{tabular}{|c|c|c|c|c|c|c|}
\hline & \multicolumn{2}{|c|}{ Stocks } & \multicolumn{2}{|c|}{ Yields } & \multicolumn{2}{|c|}{ OIS } \\
\hline & I & II & III & IV & $\mathbf{v}$ & VI \\
\hline COVID-Cases & $\begin{array}{l}-0.020 \\
(0.015)\end{array}$ & $\begin{array}{l}-0.016 \\
(0.014)\end{array}$ & $\begin{array}{c}0.001^{\star \star} \\
(0.000)\end{array}$ & $\begin{array}{r}0.000 \\
(0.000)\end{array}$ & $\begin{array}{l}-0.000 \\
(0.004)\end{array}$ & $\begin{array}{l}-0.000 \\
(0.005)\end{array}$ \\
\hline $\begin{array}{l}\text { COVID-Cases- } \\
\text { Spillover }\end{array}$ & $\begin{array}{r}0.005 \\
(0.030)\end{array}$ & $\begin{array}{r}0.000 \\
(0.028)\end{array}$ & $\begin{array}{l}-0.000 \\
(0.000)\end{array}$ & $\begin{array}{r}0.000 \\
(0.000)\end{array}$ & $\begin{array}{l}-0.001 \\
(0.001)\end{array}$ & $\begin{array}{l}-0.001 \\
(0.001)\end{array}$ \\
\hline$\Delta$ COVID-Cases & $\begin{array}{r}0.002 \\
(0.009)\end{array}$ & $\begin{array}{l}-0.004 \\
(0.006)\end{array}$ & $\begin{array}{l}-0.000 \\
(0.000)\end{array}$ & $\begin{array}{l}-0.000 \\
(0.000)\end{array}$ & $\begin{array}{l}-0.002 \\
(0.002)\end{array}$ & $\begin{array}{l}-0.002 \\
(0.003)\end{array}$ \\
\hline $\begin{array}{l}\Delta \text { COVID-Cases- } \\
\text { Spillover }\end{array}$ & $\begin{array}{l}-0.017 \\
(0.037)\end{array}$ & $\begin{array}{l}-0.010 \\
(0.035)\end{array}$ & $\begin{array}{l}-0.000 \\
(0.001)\end{array}$ & $\begin{array}{l}-0.000 \\
(0.000)\end{array}$ & $\begin{array}{l}-0.000 \\
(0.002)\end{array}$ & $\begin{array}{r}0.000 \\
(0.002)\end{array}$ \\
\hline $\begin{array}{l}\text { COVID-Cases- } \\
\text { World }\end{array}$ & $\begin{array}{r}0.244^{\star \star} \\
(0.098)\end{array}$ & $\begin{array}{r}0.207^{\star \star} \\
(0.092)\end{array}$ & $\begin{array}{r}-0.006^{\star *} \\
(0.003)\end{array}$ & $\begin{array}{r}-0.004^{*} \\
(0.002)\end{array}$ & $\begin{array}{l}-0.005 \\
(0.005)\end{array}$ & $\begin{array}{l}-0.002 \\
(0.004)\end{array}$ \\
\hline$\Delta$ COVID-Cases & $\begin{array}{r}-1.177^{\star \star} \\
(0.513)\end{array}$ & $\begin{array}{r}-0.599^{\star} \\
(0.352)\end{array}$ & $\begin{array}{l}-0.014 \\
(0.013)\end{array}$ & $\begin{array}{r}-0.020^{\star \star} \\
(0.009)\end{array}$ & $\begin{array}{l}-0.013 \\
(0.041)\end{array}$ & $\begin{array}{r}0.005 \\
(0.047)\end{array}$ \\
\hline Monetary-Events & $\begin{array}{l}-0.183 \\
(0.476)\end{array}$ & & $\begin{array}{l}-0.062 \\
(0.040)\end{array}$ & & $\begin{array}{l}-0.006 \\
(0.011)\end{array}$ & \\
\hline Monetary- & 0.004 & & 0.049 & & -0.007 & \\
\hline Events-Spillover & $(2.418)$ & & $(0.042)$ & & $(0.090)$ & \\
\hline Monetary- & & 0.130 & & -0.015 & & 0.004 \\
\hline Additional & & $(0.358)$ & & $(0.022)$ & & $(0.040)$ \\
\hline $\begin{array}{l}\text { Monetary-Addi- } \\
\text { tional-Spillover }\end{array}$ & & $\begin{array}{r}1.585 \\
(1.222)\end{array}$ & & $\begin{array}{l}-0.017 \\
(0.021)\end{array}$ & & $\begin{array}{l}-0.045 \\
(0.038)\end{array}$ \\
\hline Monetary- & & 0.025 & & $-0.041^{\star \star \star}$ & & -0.005 \\
\hline Purchase & & $(0.056)$ & & $(0.005)$ & & $(0.006)$ \\
\hline Monetary-Pur- & & 0.282 & & 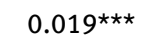 & & 0.010 \\
\hline chase-Spillover & & $(0.184)$ & & $(0.006)$ & & $(0.006)$ \\
\hline Monetary-Rate & & $\begin{array}{l}-0.478 \\
(1.774)\end{array}$ & & $\begin{array}{r}0.005 \\
(0.144)\end{array}$ & & $\begin{array}{r}0.042 \\
(0.054)\end{array}$ \\
\hline Monetary-Rate- & & -14.925 & & 0.280 & & 0.403 \\
\hline Spillover & & $(10.470)$ & & $(0.301)$ & & (1.805) \\
\hline Monetary- & & -0.757 & & -0.009 & & -0.004 \\
\hline Refinancing & & $(0.657)$ & & $(0.038)$ & & $(0.023)$ \\
\hline $\begin{array}{l}\text { Monetary-Refi- } \\
\text { nancing- }\end{array}$ & & $\begin{array}{r}-10.168^{\star \star \star} \\
(1.586)\end{array}$ & & $\begin{array}{r}0.252^{\star \star *} \\
(0.039)\end{array}$ & & $\begin{array}{r}0.054 \\
(0.241)\end{array}$ \\
\hline Spillover & & & & & & \\
\hline Fiscal-Events & $\begin{array}{l}-0.277 \\
(0.400)\end{array}$ & & $\begin{array}{r}0.025 \\
(0.019)\end{array}$ & & $\begin{array}{l}-0.008 \\
(0.052)\end{array}$ & \\
\hline $\begin{array}{l}\text { Fiscal-Events- } \\
\text { Spillover }\end{array}$ & $\begin{array}{l}-1.645 \\
(3.894)\end{array}$ & & $\begin{array}{l}0.184^{*} \\
(0.100)\end{array}$ & & $\begin{array}{r}0.227 \\
(0.161)\end{array}$ & \\
\hline Fiscal-Deferrals & & $\begin{array}{r}0.478 \\
(0.659)\end{array}$ & & $\begin{array}{r}0.023 \\
(0.030)\end{array}$ & & $\begin{array}{r}0.020 \\
(0.066)\end{array}$ \\
\hline $\begin{array}{l}\text { Fiscal-Deferrals- } \\
\text { Spillover }\end{array}$ & & $\begin{array}{r}10.789^{\star \star \star *} \\
(4.054)\end{array}$ & & $\begin{array}{l}0.315^{\star} \\
(0.181)\end{array}$ & & $\begin{array}{r}0.068 \\
(0.328)\end{array}$ \\
\hline
\end{tabular}


Table 5: (continued)

\begin{tabular}{|c|c|c|c|c|c|c|}
\hline & \multicolumn{2}{|c|}{ Stocks } & \multicolumn{2}{|c|}{ Yields } & \multicolumn{2}{|c|}{ OIS } \\
\hline & I & II & III & IV & v & VI \\
\hline Fiscal-Impulse & & $\begin{array}{r}-0.307^{\star} \\
(0.170)\end{array}$ & & $\begin{array}{l}-0.012 \\
(0.015)\end{array}$ & & $\begin{array}{l}-0.006 \\
(0.008)\end{array}$ \\
\hline Fiscal-Impulse- & & $-4.606^{\star \star \star}$ & & -0.050 & & 0.062 \\
\hline Spillover & & (1.562) & & $(0.050)$ & & $(0.106)$ \\
\hline Fiscal-Liquidity & & $\begin{array}{l}-0.095 \\
(0.075)\end{array}$ & & $\begin{array}{r}0.008^{\star \star \star} \\
(0.002)\end{array}$ & & $\begin{array}{r}0.003 \\
(0.009)\end{array}$ \\
\hline Fiscal-Liquidity- & & -0.528 & & 0.018 & & $0.029^{*}$ \\
\hline Spillover & & $(0.455)$ & & $(0.012)$ & & $(0.017)$ \\
\hline Fiscal-Shorttime & & $\begin{array}{l}-0.174 \\
(0.506)\end{array}$ & & $\begin{array}{r}0.013 \\
(0.031)\end{array}$ & & $\begin{array}{l}-0.022 \\
(0.118)\end{array}$ \\
\hline $\begin{array}{l}\text { Fiscal-Shorttime- } \\
\text { Spillover }\end{array}$ & & $\begin{array}{r}4.037 \\
(6.014)\end{array}$ & & $\begin{array}{r}0.063 \\
(0.165)\end{array}$ & & $\begin{array}{l}-0.295 \\
(0.316)\end{array}$ \\
\hline Fiscal-EU & $\begin{array}{r}-0.852^{\star} \\
(0.442)\end{array}$ & & $\begin{array}{r}0.006 \\
(0.028)\end{array}$ & & $\begin{array}{r}0.006 \\
(0.018)\end{array}$ & \\
\hline $\begin{array}{l}\text { Fiscal- } \\
\text { EU-Spillover }\end{array}$ & $\begin{array}{r}0.613 \\
(1.986)\end{array}$ & & $\begin{array}{r}0.016 \\
(0.063)\end{array}$ & & $\begin{array}{r}0.045 \\
(0.042)\end{array}$ & \\
\hline Fiscal- & & -3.844 & & -0.029 & & 0.238 \\
\hline EU-Impulse & & (2.593) & & $(0.082)$ & & $(0.273)$ \\
\hline Fiscal- & & -0.161 & & $0.428^{\star \star}$ & & 0.102 \\
\hline $\begin{array}{l}\text { EU-Impulse- } \\
\text { Spillover }\end{array}$ & & (5.636) & & $(0.205)$ & & $(0.351)$ \\
\hline Fiscal- & & -29.490 & & $0.006^{\star \star}$ & & 0.000 \\
\hline EU-Liquidity & & $(41.906)$ & & $(0.003)$ & & $(0.013)$ \\
\hline Fiscal- & & $0.772^{\star \star \star}$ & & $-0.015^{\star \star \star}$ & & 0.005 \\
\hline EU-Liquidity- & & $(0.146)$ & & (0.004) & & $(0.011)$ \\
\hline Spillover & & & & & & \\
\hline Fiscal-EU-SGP & & $\begin{array}{r}-0.698^{\star \star \star} \\
(0.173)\end{array}$ & & $\begin{array}{r}-0.046^{\star \star *} \\
(0.010)\end{array}$ & & $\begin{array}{l}-0.011 \\
(0.108)\end{array}$ \\
\hline Fiscal-EU-SGP- & & $6.109^{\star \star \star}$ & & $0.076^{\star \star \star}$ & & 0.104 \\
\hline Spillover & & (1.054) & & $(0.026)$ & & $(0.122)$ \\
\hline Google- & -0.089 & -0.079 & 0.003 & 0.003 & -0.005 & -0.004 \\
\hline Residential & $(0.085)$ & $(0.078)$ & $(0.004)$ & $(0.004)$ & $(0.004)$ & $(0.004)$ \\
\hline $\begin{array}{l}\text { Google-Residen- } \\
\text { tial-Spillover }\end{array}$ & $\begin{array}{l}-0.093 \\
(0.399)\end{array}$ & $\begin{array}{l}-0.060 \\
(0.363)\end{array}$ & $\begin{array}{r}0.007 \\
(0.009)\end{array}$ & $\begin{array}{r}0.004 \\
(0.006)\end{array}$ & $\begin{array}{r}0.006 \\
(0.023)\end{array}$ & $\begin{array}{r}0.007 \\
(0.020)\end{array}$ \\
\hline Google-Transit & $\begin{array}{l}-0.007 \\
(0.012)\end{array}$ & $\begin{array}{l}-0.005 \\
(0.011)\end{array}$ & $\begin{array}{r}0.001 \\
(0.001)\end{array}$ & $\begin{array}{r}0.001 \\
(0.001)\end{array}$ & $\begin{array}{l}-0.001 \\
(0.001)\end{array}$ & $\begin{array}{l}-0.001 \\
(0.001)\end{array}$ \\
\hline Google-Transit- & -0.076 & -0.030 & -0.001 & -0.000 & 0.002 & 0.002 \\
\hline Spillover & $(0.092)$ & $(0.088)$ & $(0.002)$ & $(0.002)$ & $(0.003)$ & $(0.002)$ \\
\hline Google- & -0.004 & -0.006 & 0.000 & 0.000 & 0.000 & 0.000 \\
\hline Workplace & $(0.008)$ & $(0.363)$ & $(0.000)$ & $(0.000)$ & $(0.000)$ & $(0.000)$ \\
\hline
\end{tabular}


Table 5: (continued)

\begin{tabular}{|c|c|c|c|c|c|c|}
\hline & \multicolumn{2}{|c|}{ Stocks } & \multicolumn{2}{|c|}{ Yields } & \multicolumn{2}{|c|}{ OIS } \\
\hline & I & II & III & IV & v & VI \\
\hline Google-Work- & 0.012 & -0.008 & 0.000 & 0.000 & -0.001 & -0.001 \\
\hline place-Spillover & $(0.029)$ & $(0.025)$ & $(0.000)$ & $(0.000)$ & $(0.003)$ & $(0.002)$ \\
\hline Adjusted $R^{2}$ & 0.18 & 0.39 & 0.04 & 0.16 & 0.00 & 0.00 \\
\hline$N$ & 1262 & 1262 & 1190 & 1190 & 1363 & 1363 \\
\hline
\end{tabular}

The dependent variable is the daily change in the yield on 10-year government bonds (in percentage points). We include country fixed effects. Robust standard errors in parentheses. A significance level of 1,5 and $10 \%$ is denoted by $* * *$, ** and *.

Finland, Denmark, Sweden, Poland, Czech Republic, Hungary, Romania, Norway, Switzerland and the UK.

Table 6 presents the estimated coefficients when we narrow the set of countries to euro area member countries. ${ }^{19}$

Throughout the alternative specifications, ECB announcements summarized by the variables Monetary-Refinancing lead to a strong fall in stock prices. Broadly defined fiscal policy supports higher stock prices, while the effect is diminished for countries more strongly affected by the pandemic. Fiscal policy, in particular a policy easing implemented through deferrals of tax payments, raises stock prices. Again, we find that stimulus measures adopted at the EU levels reduce equity prices, while the suspension of the SGP boosts asset prices.

The corresponding results for the change in bond yields are reported in Table 7. Monetary-Refinancing, Fiscal-Liquidity and fiscal policies announced at the level of the European Union, in particular the stimulus measures, raise bond yields. Markets seem to be aware that the relaxation of the constraints imposed through the SGP eventually lead to a larger fiscal burden, such that European bond yields increase. In contrast to the equity market response, the announcement of short-term work programs lowers governments' borrowing costs.

Lastly, we estimate the model for relatively large economies only. Table 8 reports the estimated coefficients of the model when the stock market return is the dependent variable. Again, fiscal announcements contribute to a higher stock market valuation. The impact falls in the growth rate of COVID-19 cases. The remaining coefficients do not change much with respect to the baseline results with

19 The row with the first policy measure is left blank if the first announcement was not associated with this category or when there is only one announcement in this category. Furthermore, there are no coefficients on the Monetary-Rate variable since the ECB did not change interest rates in the sample period. 


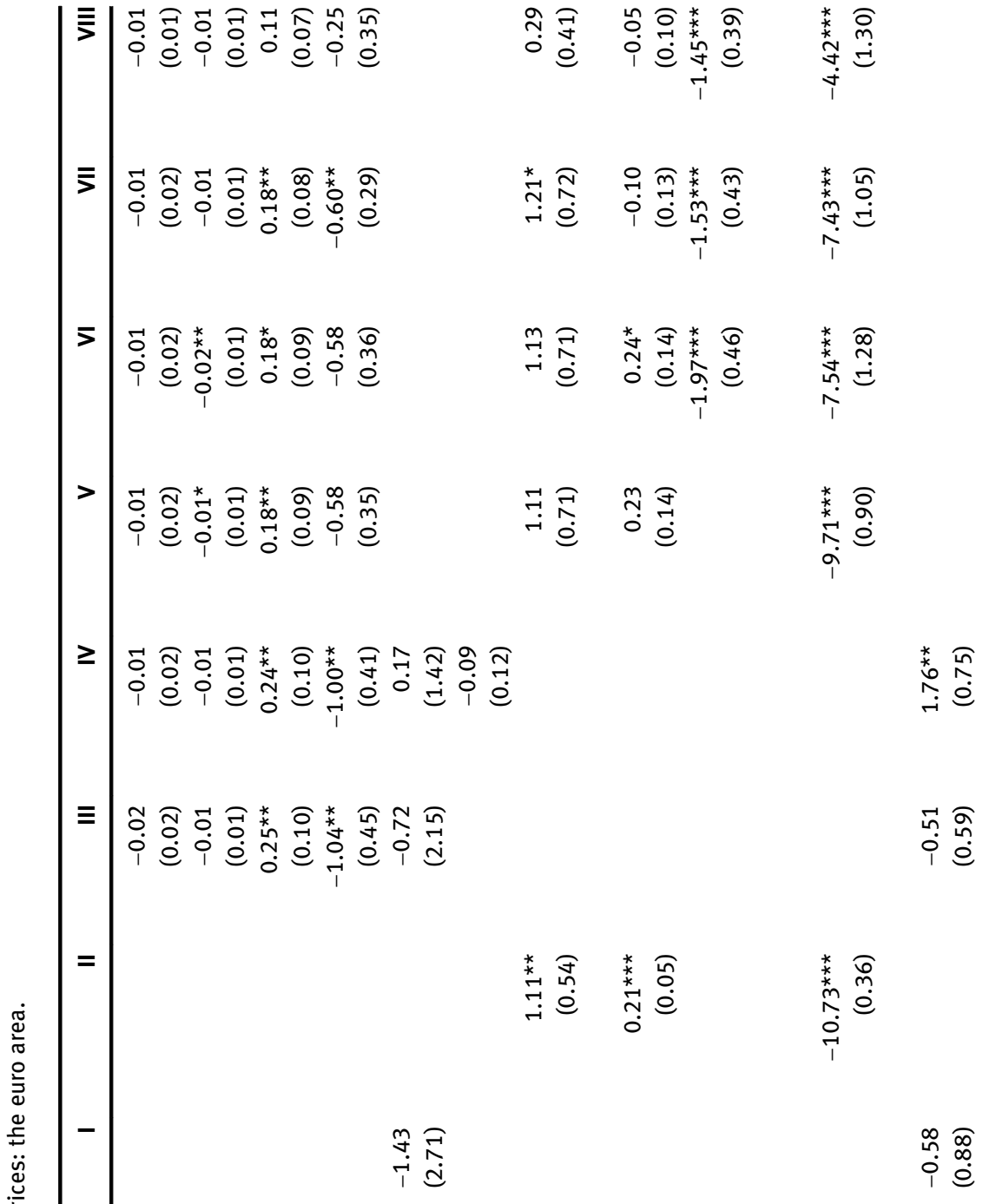

$$
\begin{aligned}
& \text { 言 }
\end{aligned}
$$




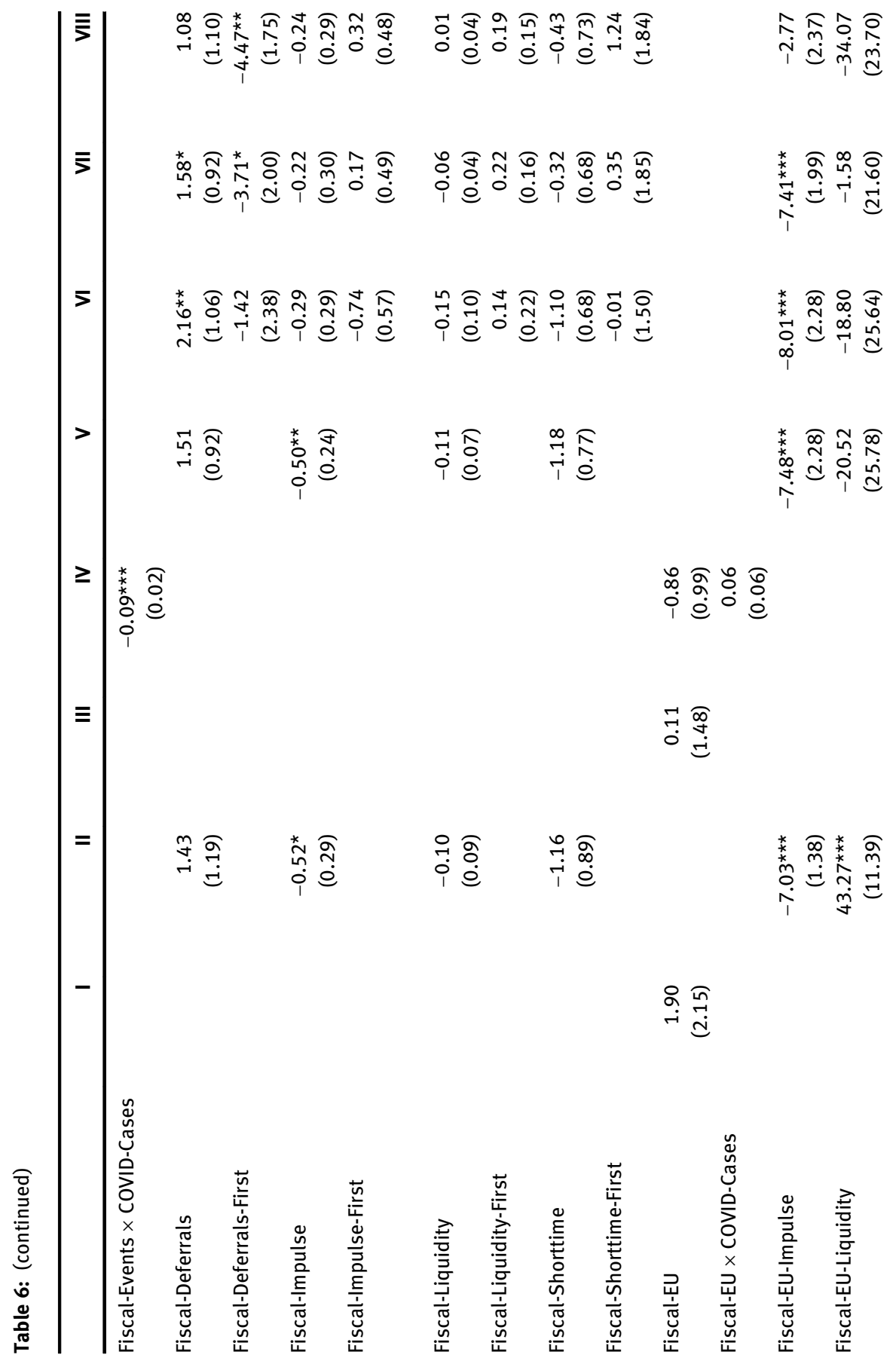




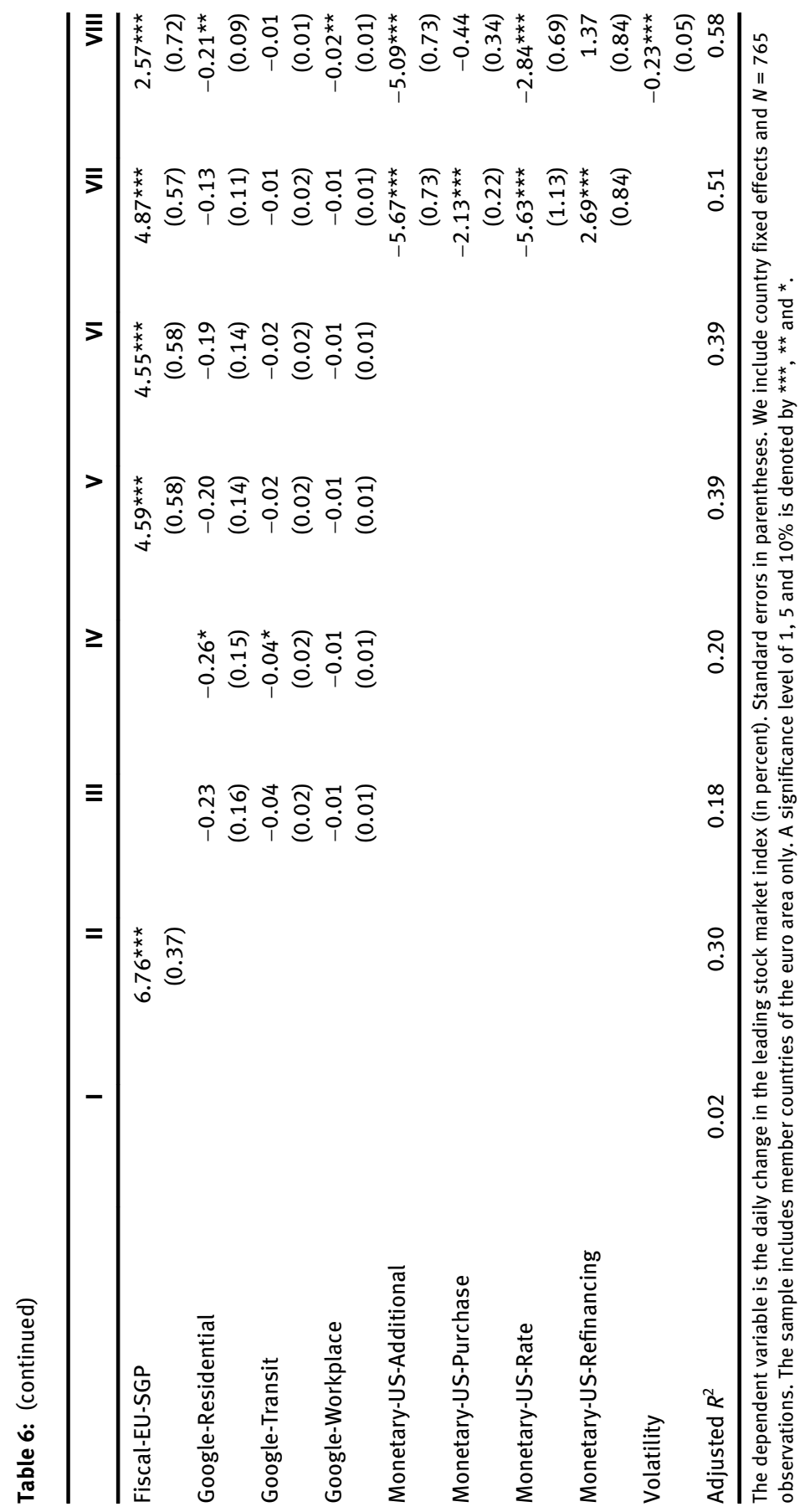




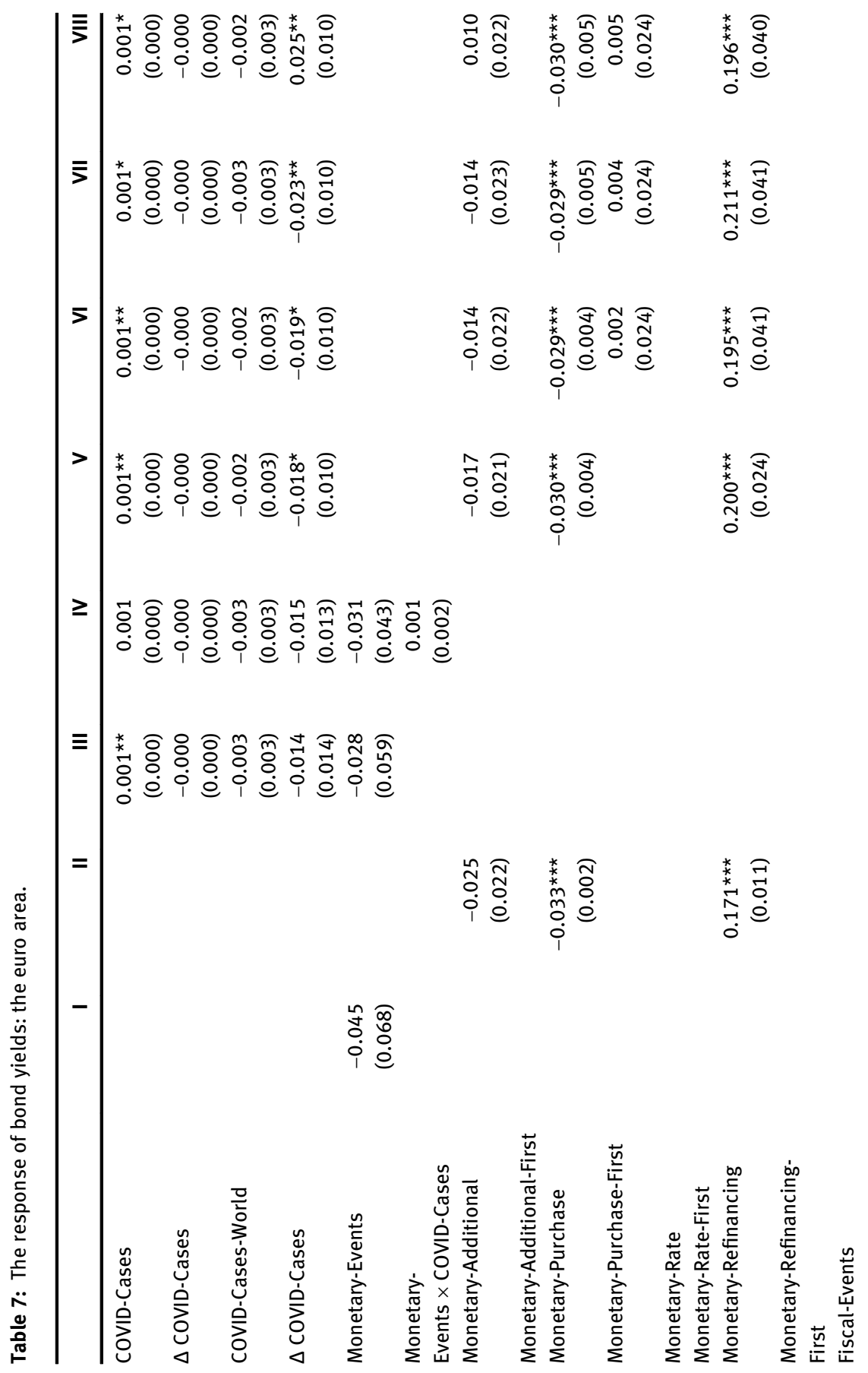




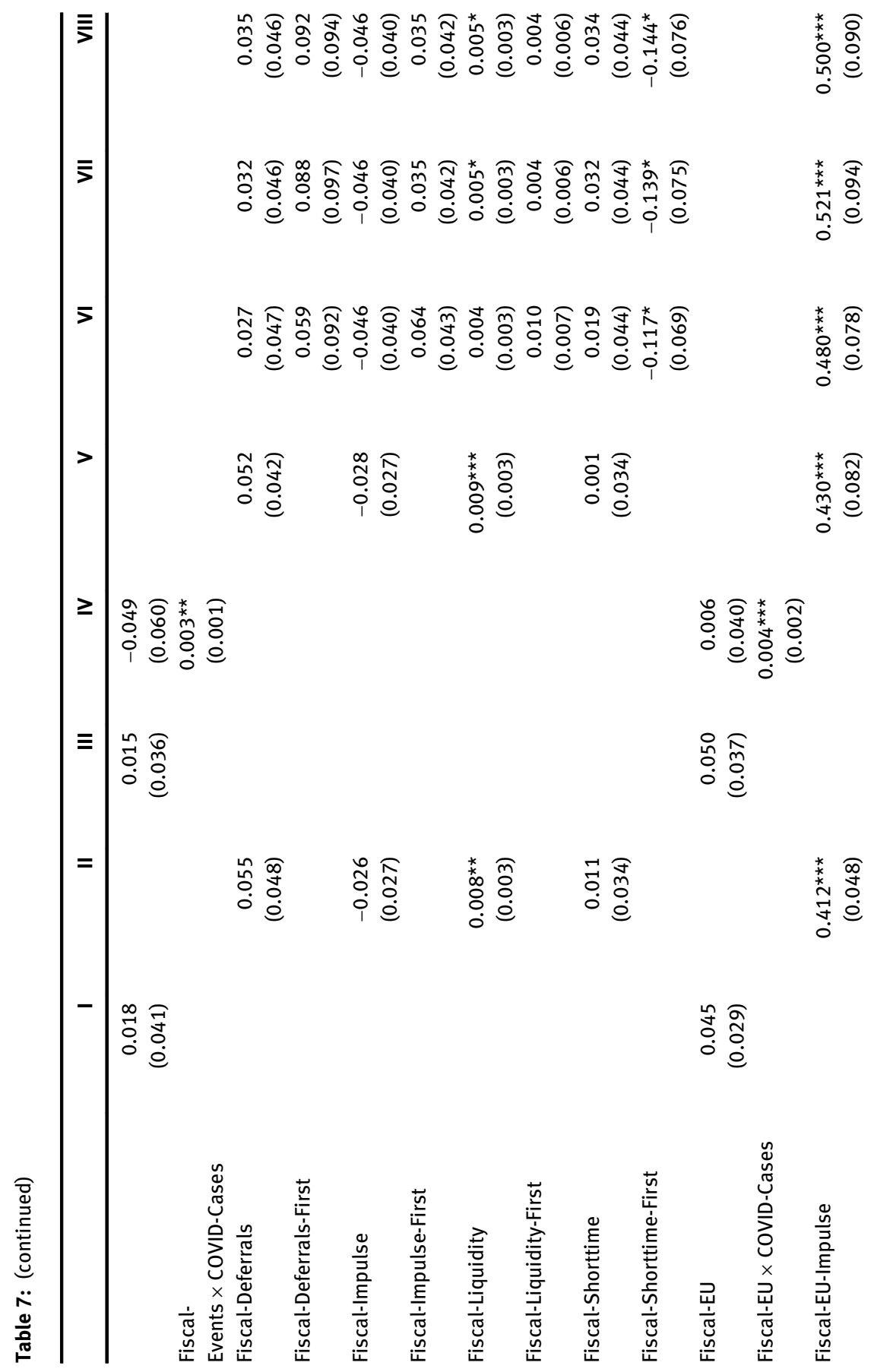




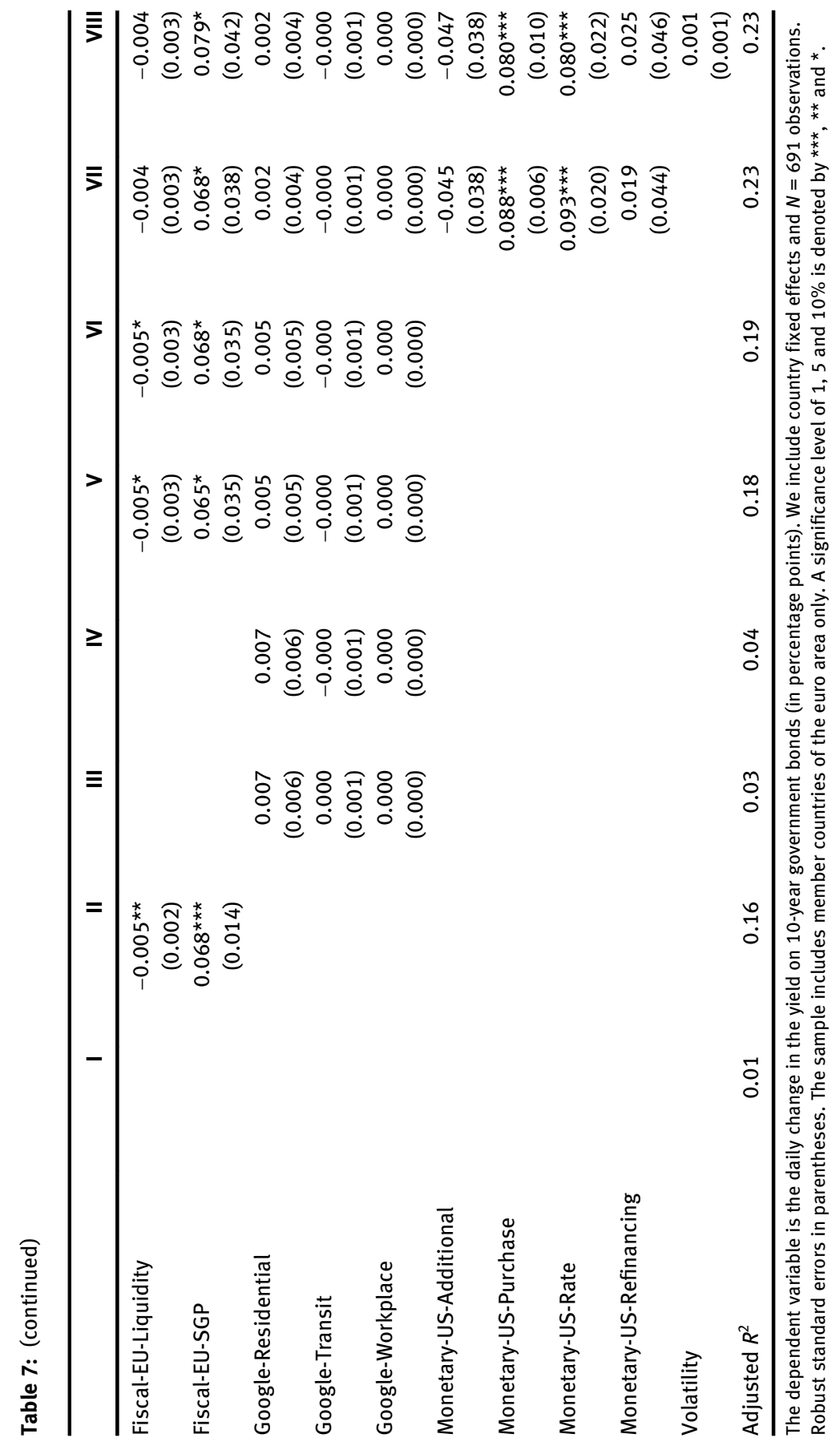




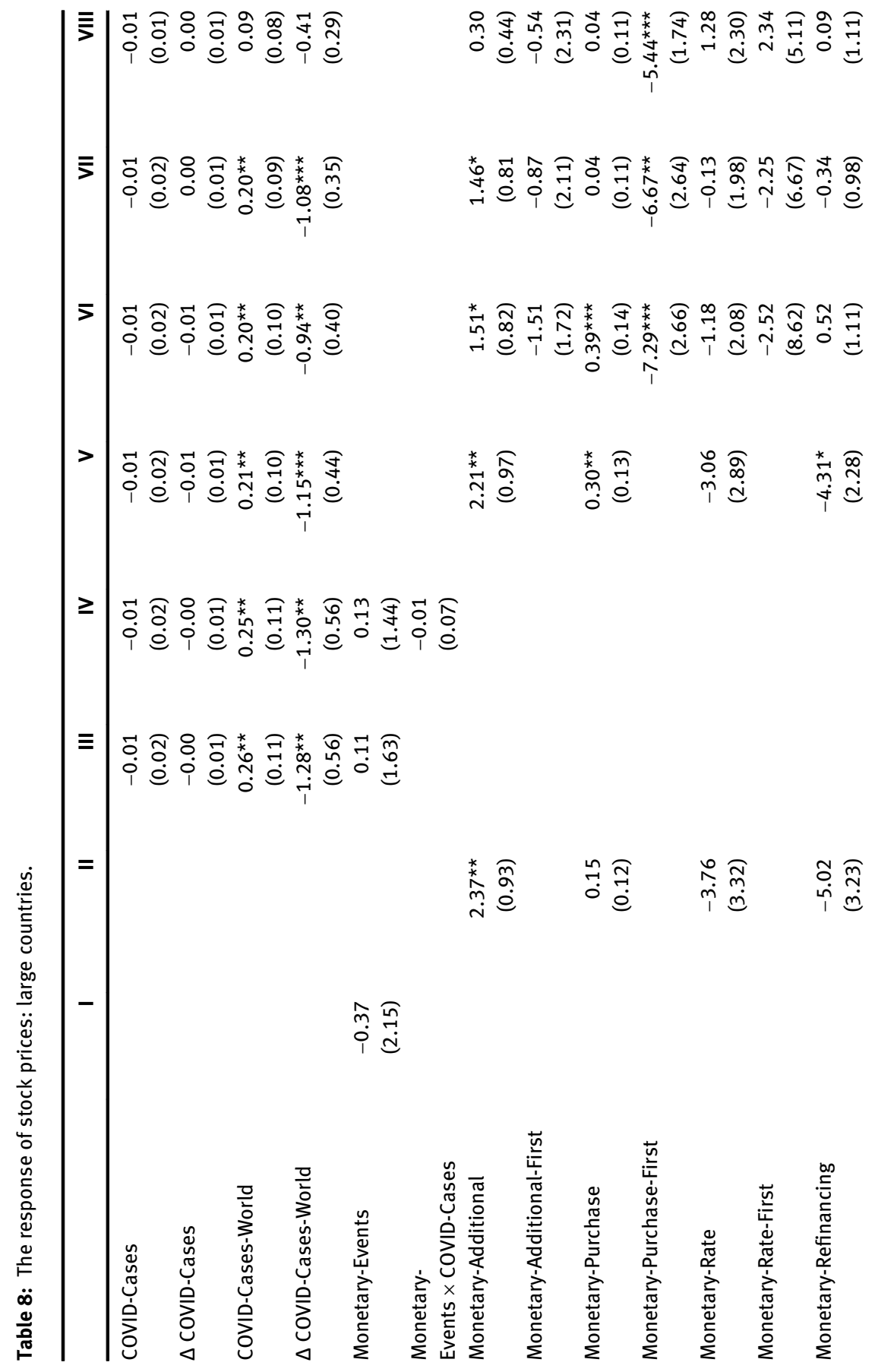




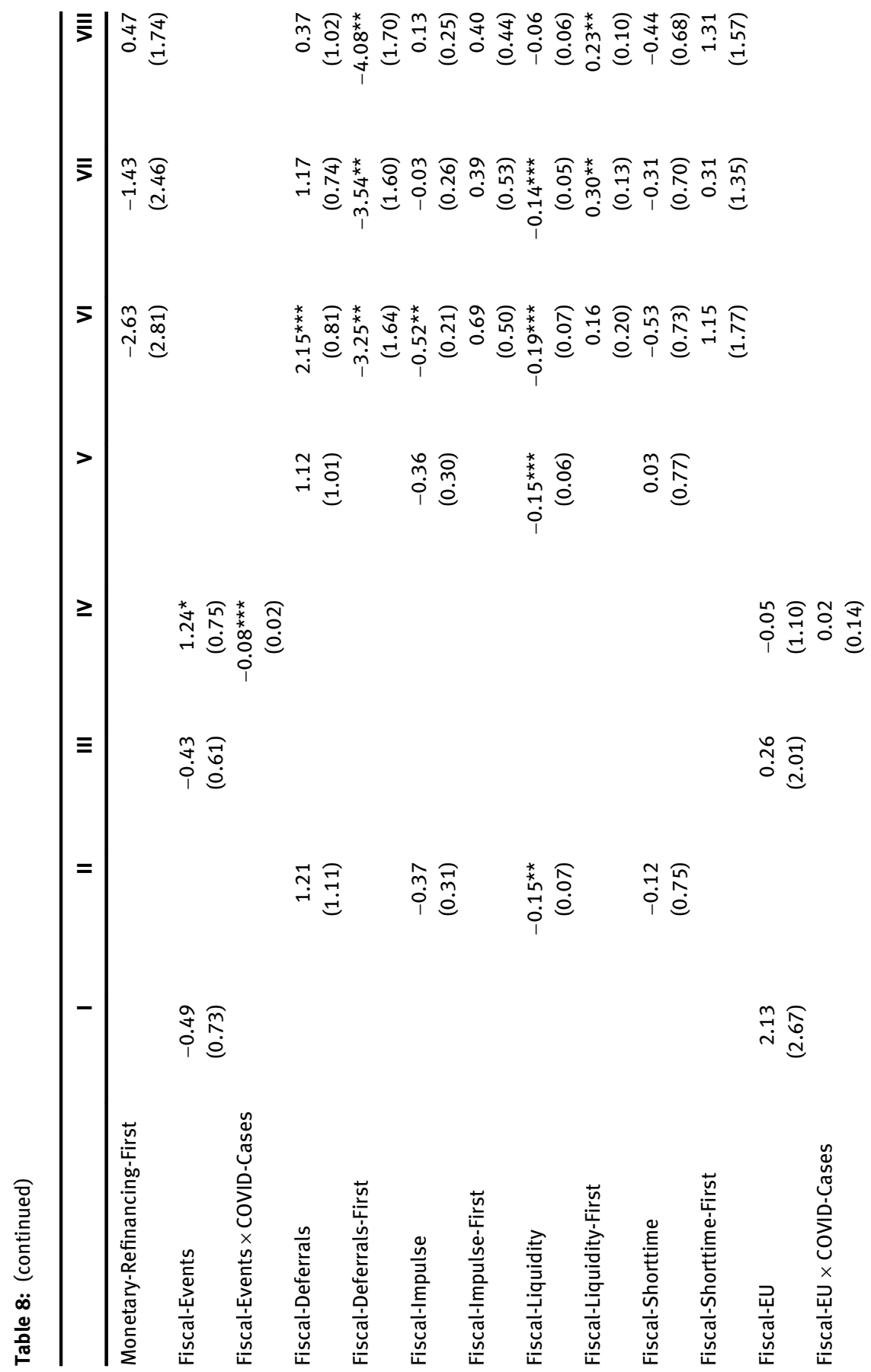




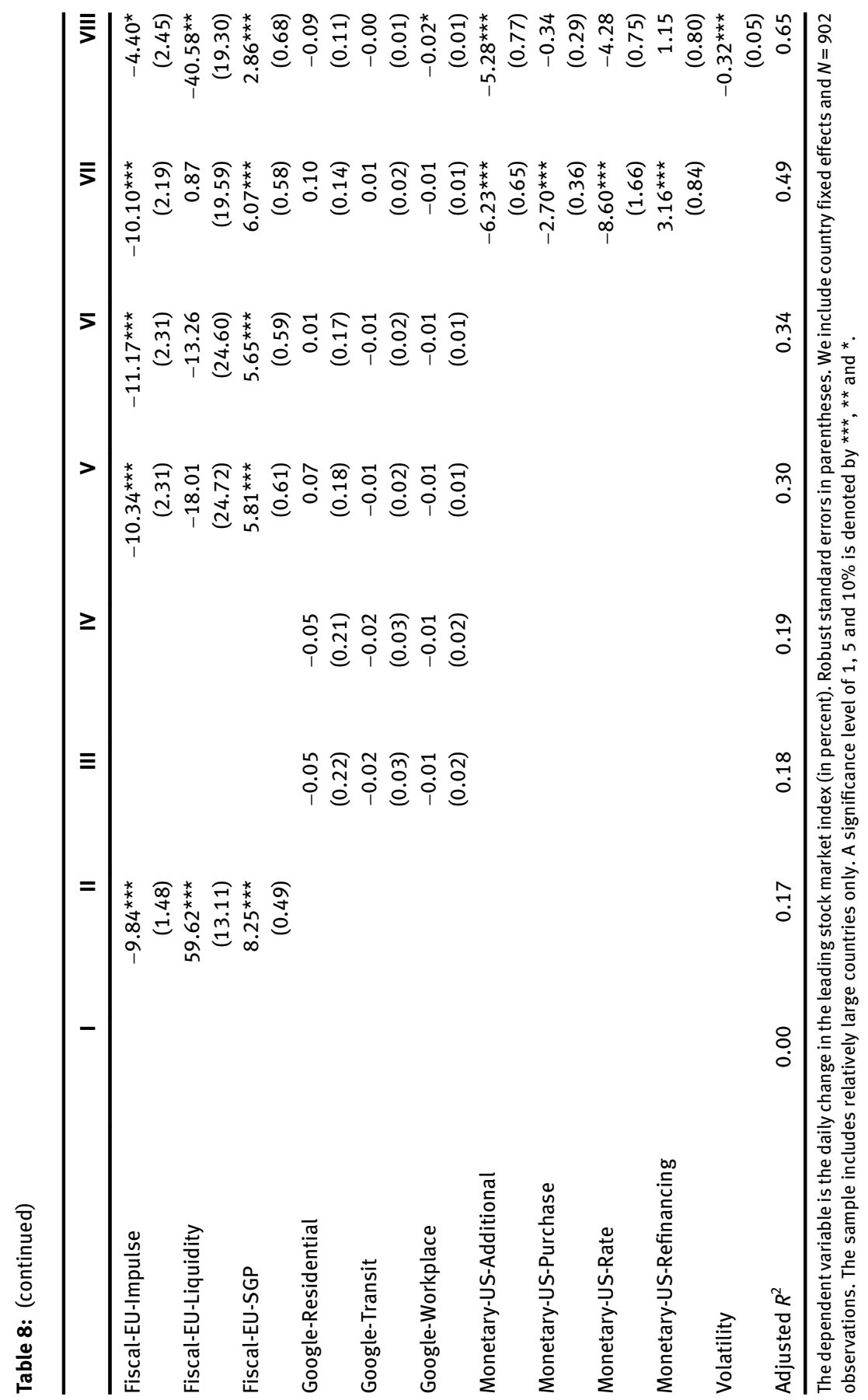




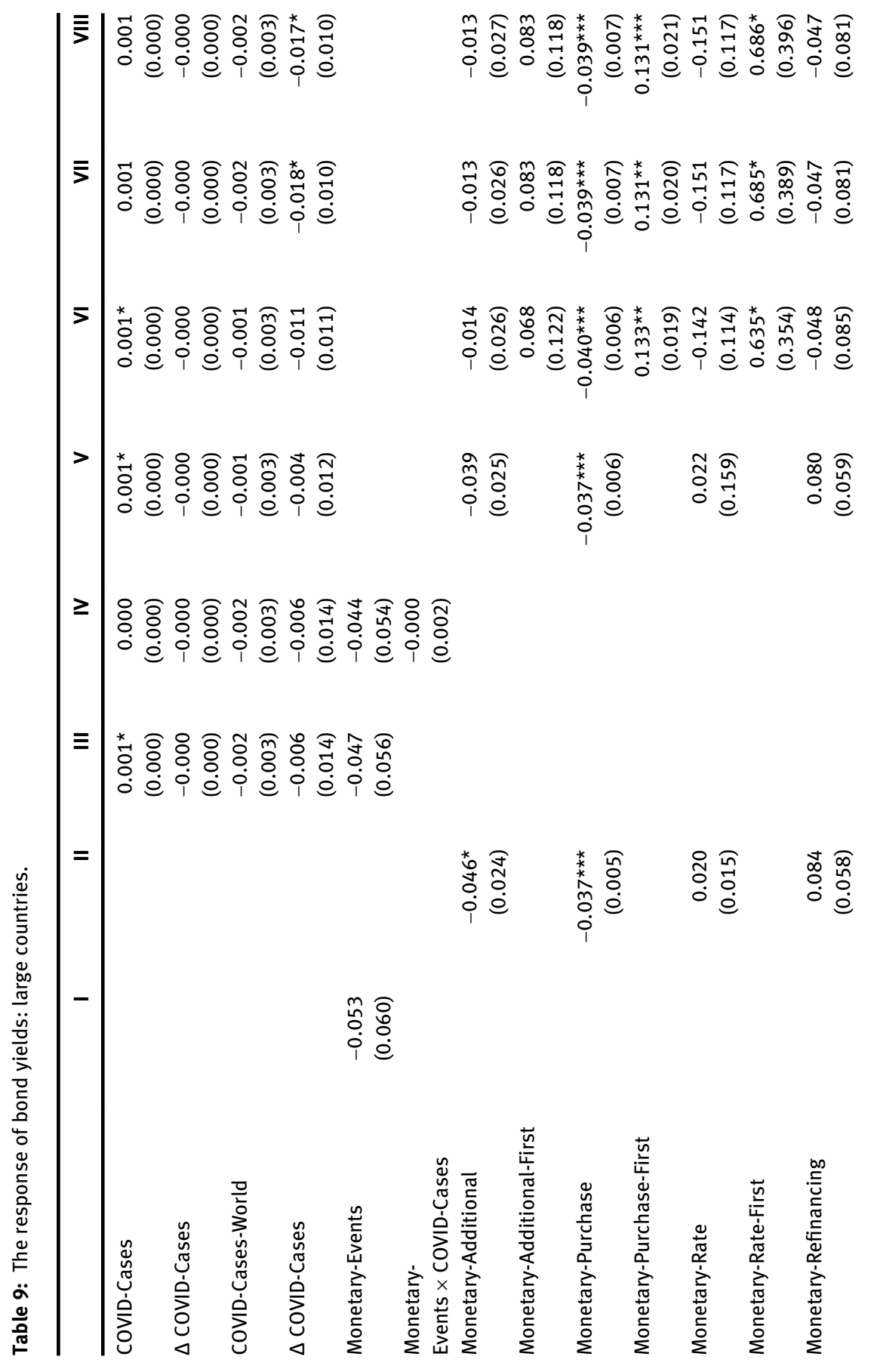




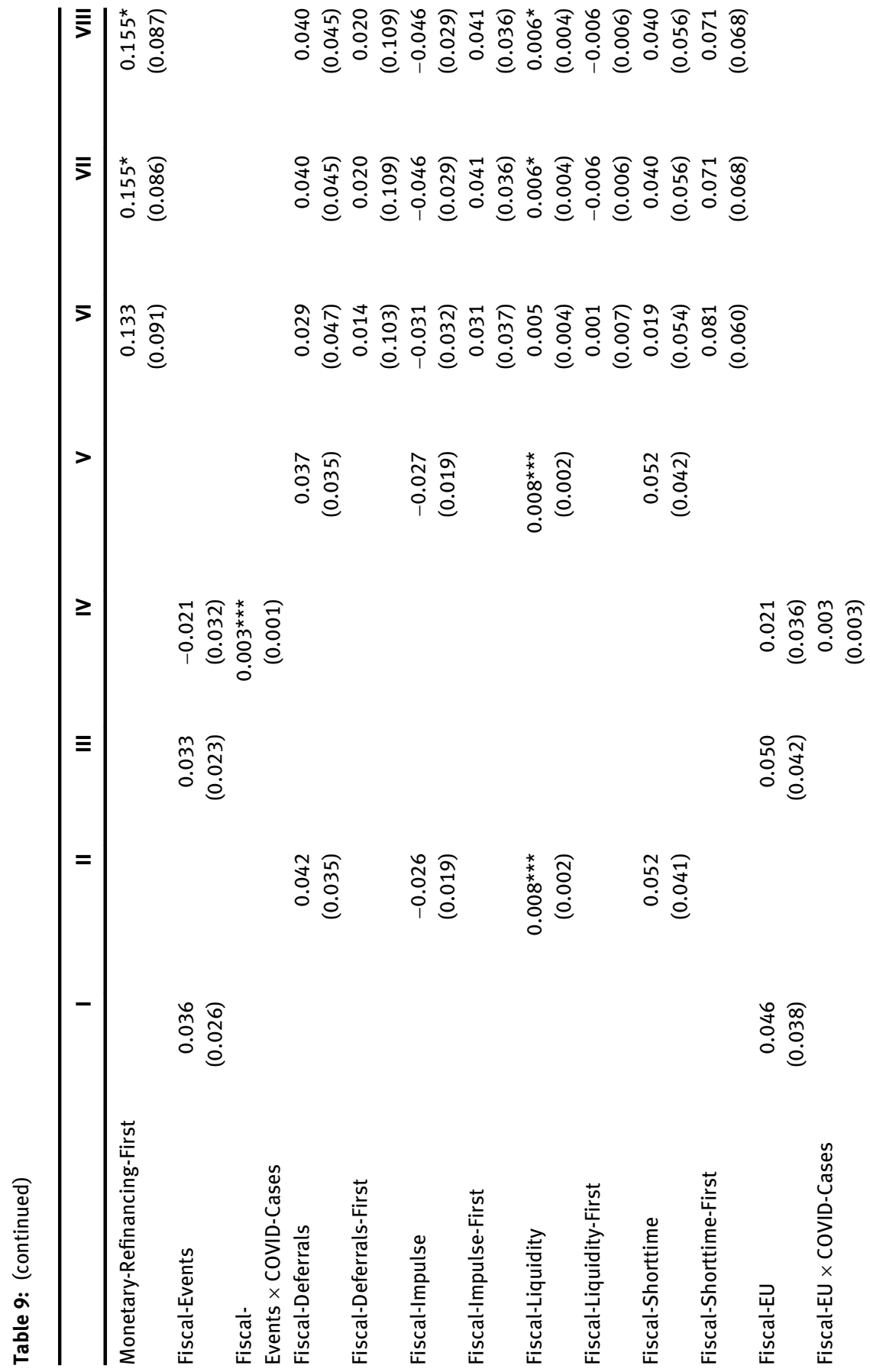




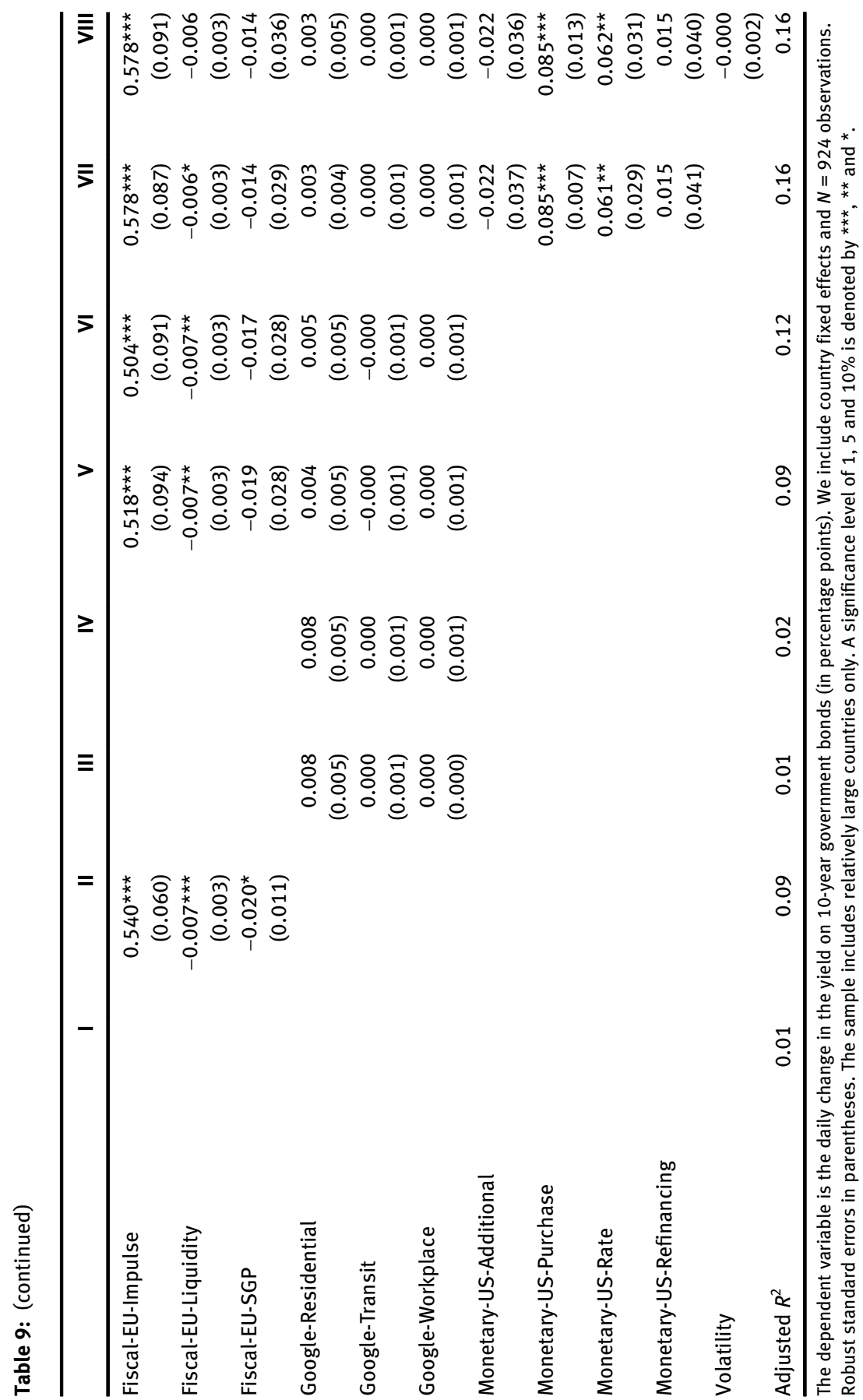




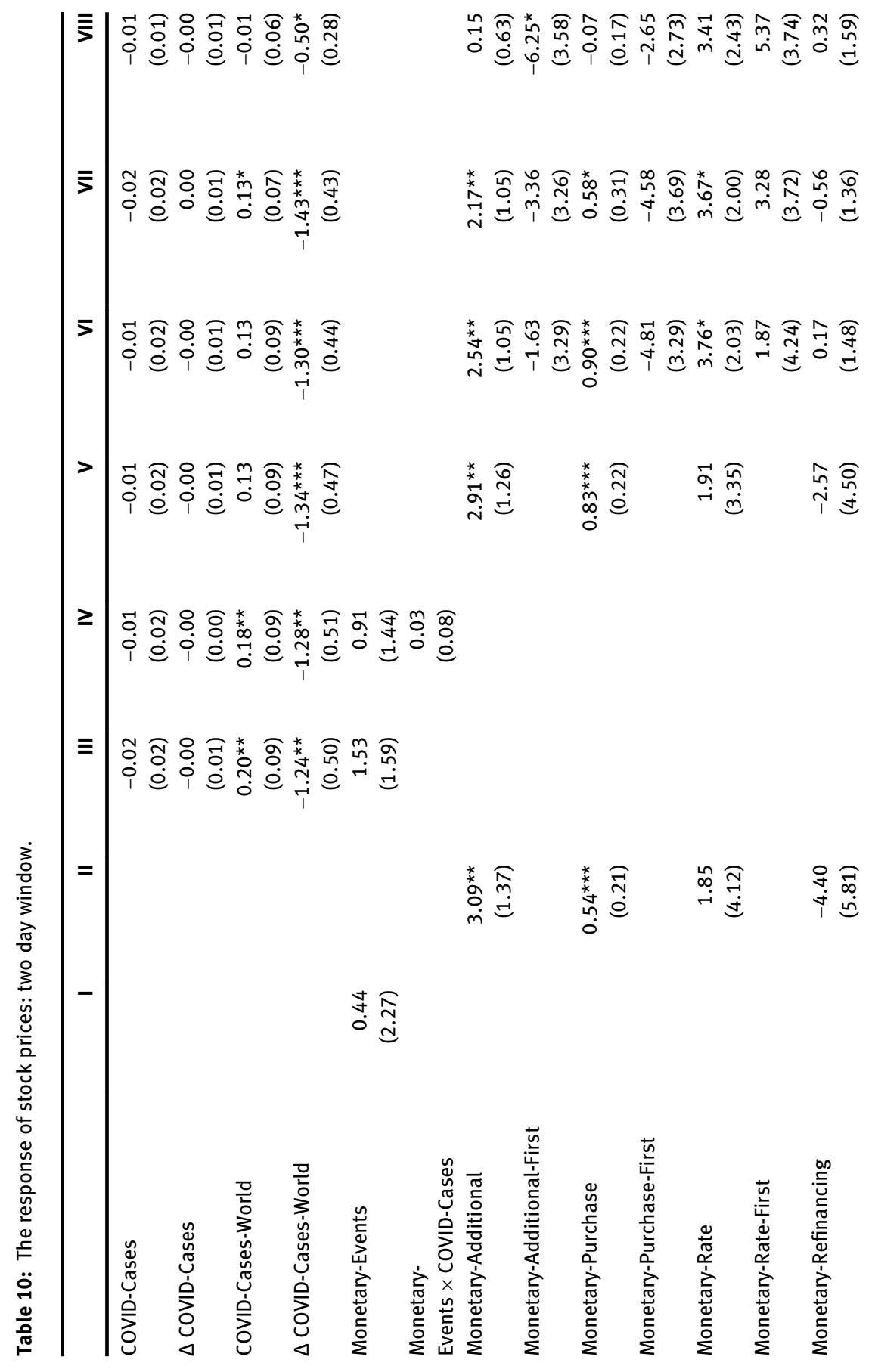




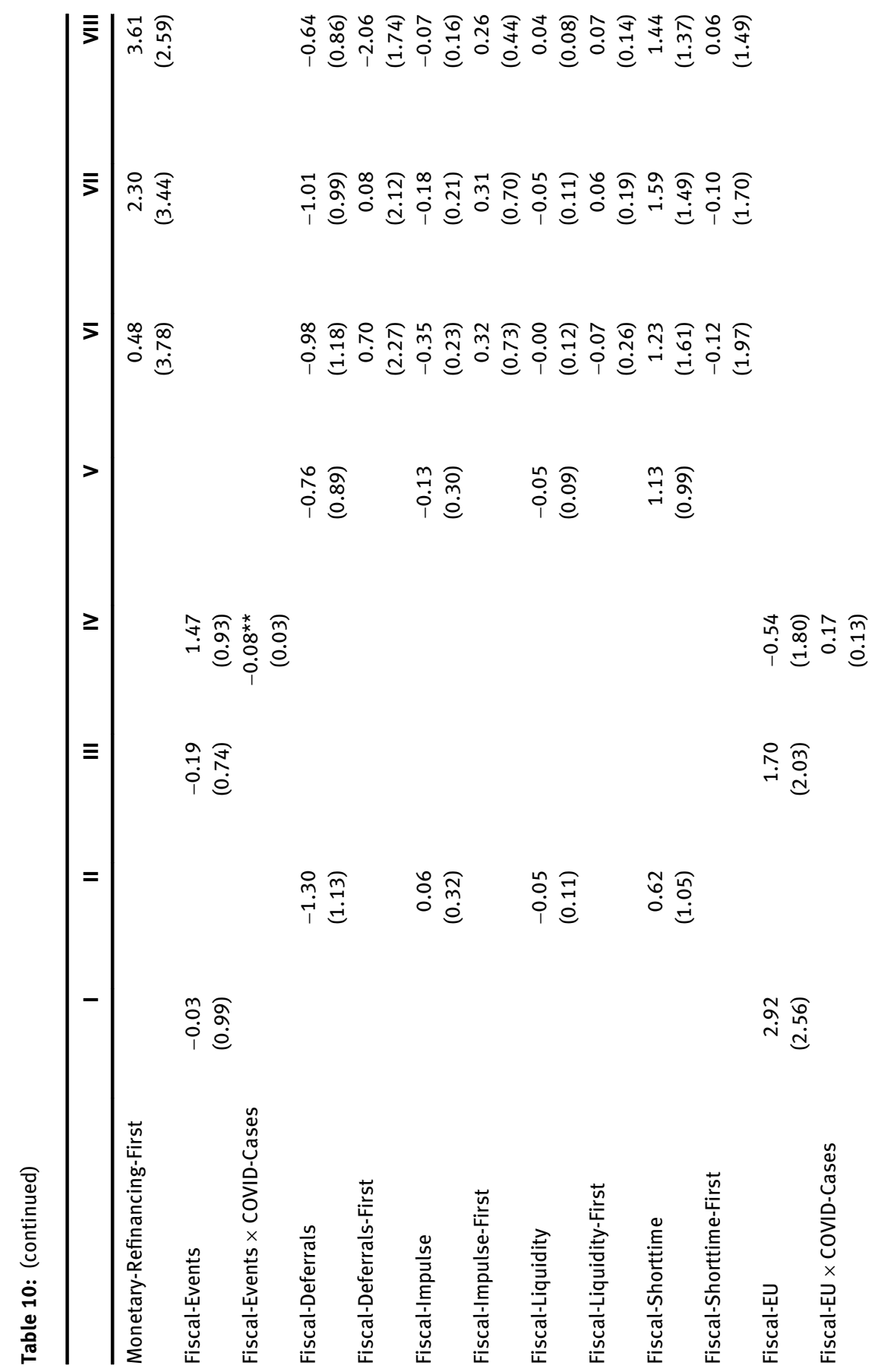




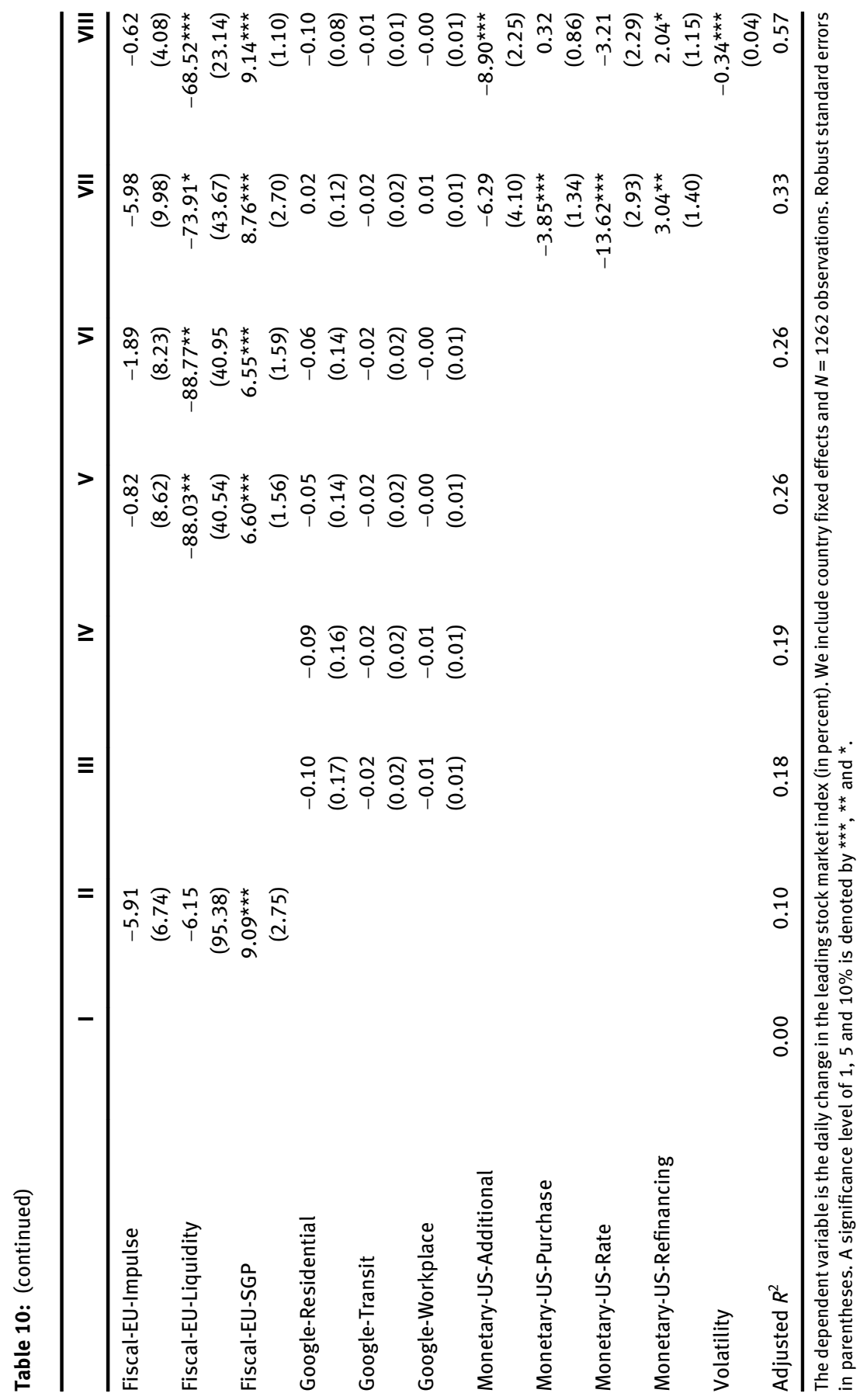




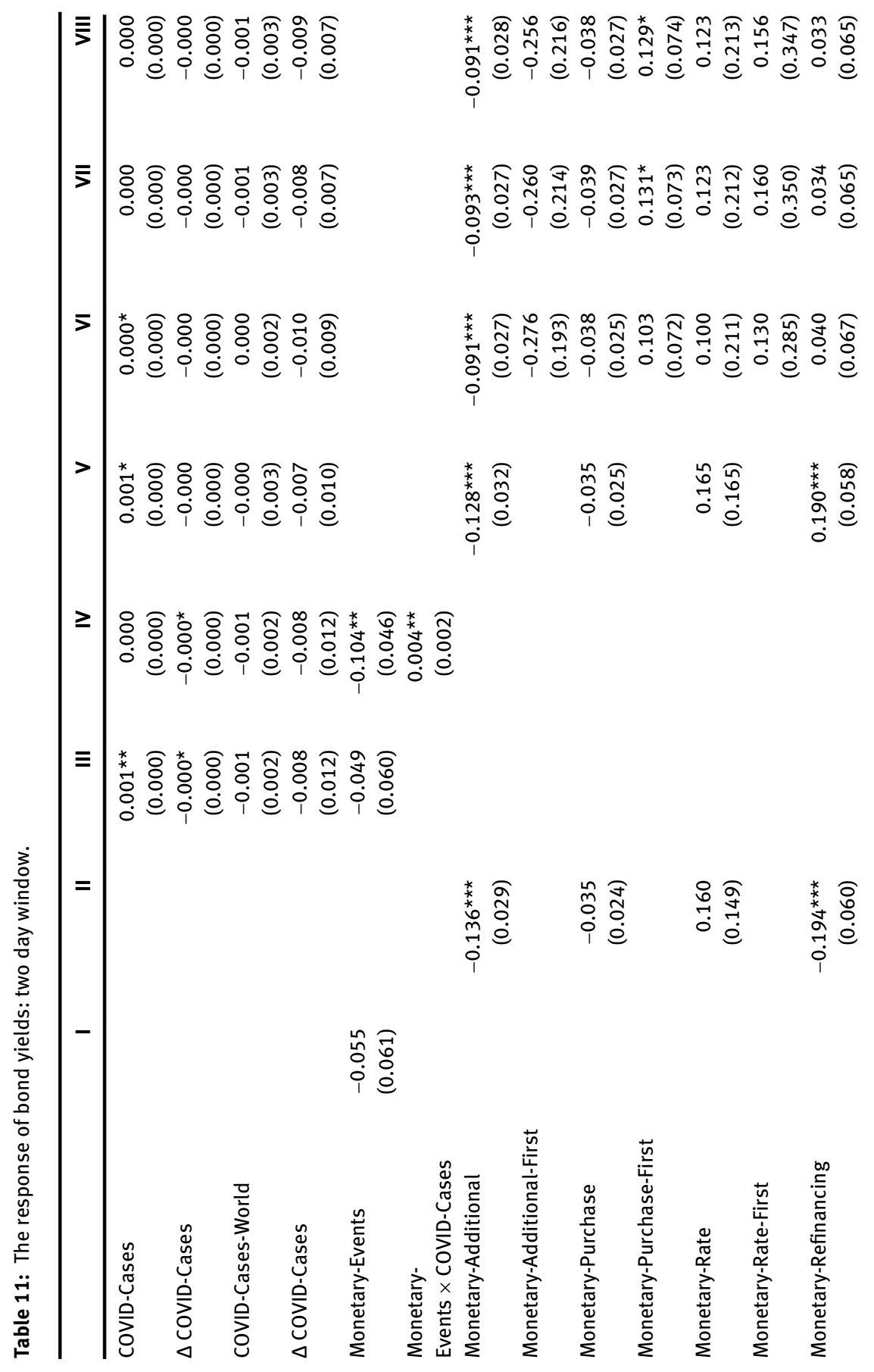




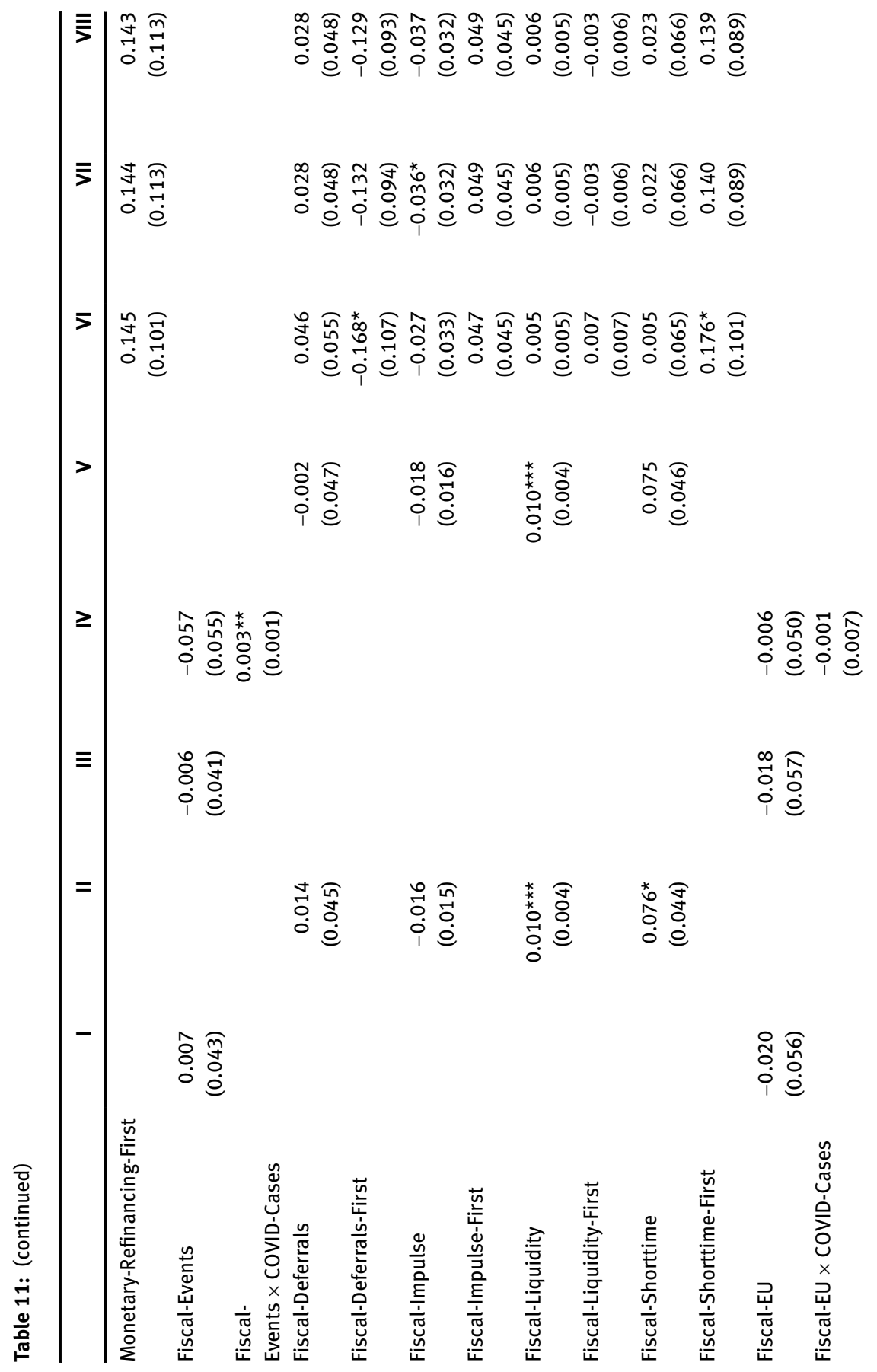




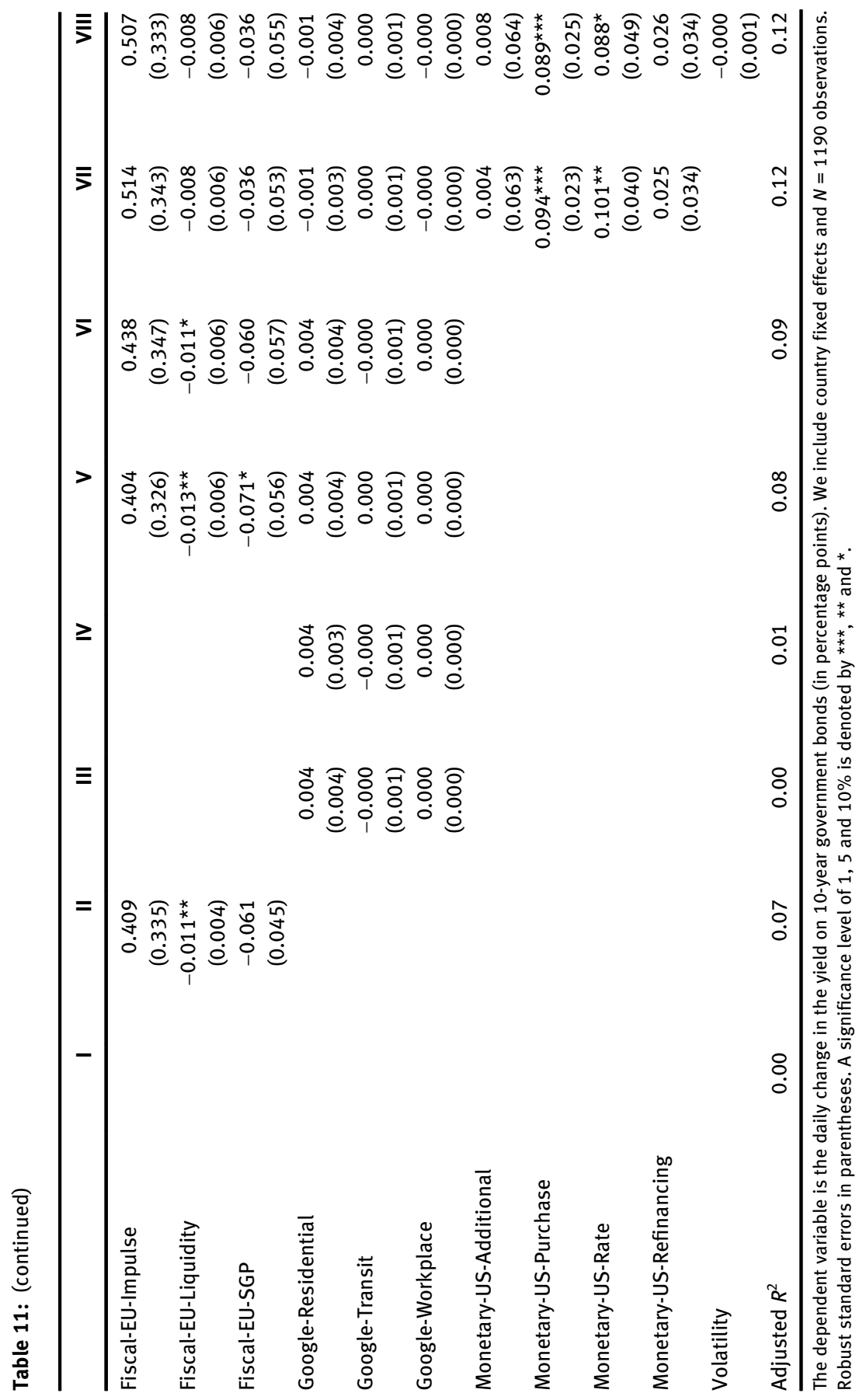


Monetary-Additional as well as the suspension of the SGP being highly effective in pushing equity market valuations.

National fiscal liquidity measures and European fiscal impulses, raise bond yields, see Table 9. In contrast the purchase programmes initiated by the central banks significantly eased refinancing conditions for governments.

\subsection{Two-day Event Window}

The dependent variable, $\Delta y_{t, i}$, is either the percentage change of the leading stock market index (in percent) or the change in the yield on a 10-year government bond (in percentage points) of country $i$ at time $t$. Like other event studies, we assume that the market immediately adjusts to the announcement made on the same day. We now want to rule out that the results are sensitive to the choice of the event window. In fact, significant market moves often happen on the days following the initial announcement. We follow Krishnamurthy et al. (2018) and allow for a twoday event window. The event dummies are coded as ...,0,0,1/2,1/2,0,0,.. instead of $\ldots, 0,0,1,0,0,0, \ldots$ in order to facilitate the comparison with the original results.

Table 10 reports the estimated coefficients. In general, the results become somewhat stronger than in the baseline specification. Monetary-Additional events and Monetary-Purchase announcements have a positive and strongly significant effect on stock prices. Liquidity measures at the European level lower stocks, while the SGP dummy again leads to higher stock prices. Consistently, bond yields fall as a consequence of Monetary-Additional and Monetary-Refinancing announcements as shown in Table 11. National fiscal liquidity injections, in contrast, raise bond yields.

\section{Conclusions}

Governments and central banks responded to the economic consequences of the Corona pandemic with a variety of policy measures. Fiscal policy, both at the national level and the European level, and monetary policy implemented stimulus packages and announced emergency assistance unprecedented in scope and size. In this paper, we study the response of financial markets to policy announcements following the outbreak of the pandemic. One major contribution of this paper is a broad, disaggregated set of over 400 policy announcements, which we use as explanatory variables in a panel model for European countries.

Markets respond to the evolution of COVID-19 cases with a drop in stock prices and an increase in government bond yields. We find that some, but not all, measures 
were effective in calming financial markets. Asset purchases of the central bank reduce sovereign yields, while announcements of a European fiscal stimulus contribute to higher yields. Stock prices rise following announcements of tax deferrals of national fiscal policymakers and the suspension of the European SGP.

The effects of policy on asset prices depend on the exposure of countries to the Corona pandemic. A country which is afflicted with a high growth rate of Corona cases could experience an increase in bond yields on days of a fiscal policy announcement, while the same announcement leaves yields of less-affected countries unchanged.

We also provide evidence in favor of policy coordination, both across borders and between branches of policy. A fiscal announcements that coincides with a monetary announcement, for example, is particularly effective. Policy announced in one European economy also have cross-border effects on asset prices.

At the time of writing, it appears that the economic costs of fighting the virus, i.e., the drop in income and employment, are different across countries. While this paper studied announcement effects on short-term financial variables only, it remains to be seen whether the policy measures are effective in stabilizing the real economy.

\section{References}

Albulescu, C.T. (2020). COVID-19 and the United States financial markets' volatility. Finance Res. Lett. 38: 101699.

Alfaro, L.A.C., Greenland, A.N., and Schott, P.K. (2020). Aggregate and firm-level stock returns during pandemics, in real time, NBER Working Paper No. 26950. National Bureau of Economic Research, Cambridge.

Ashraf, N.N. (2020a). Economic impact of government interventions during the COVID-19 pandemic: international evidence from financial markets. J. Behav. Exp. Finance 27: 100371.

Ashraf, B.N. (2020b). Stock markets' reaction to COVID-19: cases or fatalities? Res. Int. Bus. Finance 54: 101249.

Baker, S.R., Bloom, N., Davis, S.J., Kost, K., Sammon, M., and Viratyosin, T. (2020). The unprecedented stock market reaction to COVID-19. Rev. Asset Pricing Stud. 10: 742-758.

Benmelech, E. and Tzur-Ilan, N. (2020). The determinants of fiscal and monetary policies during the COVID-19 crisis, NBER Working Paper No. 27461. National Bureau of Economic Research, Cambridge.

Cheng, C., Barcelo, J., Hernett, A.S., Kubinec, R., and Messerschmidt, L. (2020). COVID-19 government response event dataset. Nat. Hum. Behav. 4: 756-768.

Conrad, C. and Zumbach, K.U. (2016). The effect of political communication on European financial markets during the sovereign debt crisis. J. Empir. Finance 39: 2019-14.

Corbet, S., Hou, Y.G., Hu, Y., Oxley, L., and Xu, D. (2021). Pandemic-related financial market volatility spillovers: evidence from the Chinese COVID-19 epicentre. Int. Rev. Econ. Finance 71: $55-81$. 
Delatte, A.-L. and Guillaume, A. (2020). COVID-19: a new challenge for the EMU, CEPR Discussion Paper No. 14848. Centre for Economic Policy Research, London.

D'Orazio, P., and Dirks, A.W. (2020). COVID-19 and financial markets: assessing the impact of the coronavirus on the Eurozone, Ruhr Economic Papers No. 859. RWI - Leibniz-Institut für Wirtschaftsforschung, Essen.

Ettmeier, S., Kim, C.H., and Kriwoluzky, A. (2020). Financial market participants expect the Coronavirus Pandemic to have long-lasting economic impact in Europe, DIW Weekly Report 19+20, 2020. Deutsches Institut für Wirtschaftsforschung.

Hartley, J.S. and Rebucci, A. (2020). An event study of COVID-19 central bank Quantitative Easing in advanced and emerging economies, NBER Working Paper No. 27339. National Bureau of Economic Research, Cambridge.

Heyden, K.J. and Heyden, T. (2021). Market reactions to the arrival and containment of COVID-19: an event study. Finance Res. Lett. 38: 101745.

Jarocinski, M. and Karadi, P. (2020). Deconstructing monetary policy surprises - the role of information shocks. Am. Econ. J. Macroecon. 12: 1-43.

Krishnamurthy, A., Nagel, S., and Vissing-Jorgenson, A. (2018). ECB policies involving government bond purchases: impacts and channels. Rev. Finance 22: 1-44.

Lyócsa, Š., Baumöhl, E., Výrost, T., and Molnár, P. (2020). Fear of the coronavirus and the stock markets. Finance Res. Lett. 36: 101735.

Ramelli, S. and Wagner, A.F. (2020). Feverish stock price reactions to COVID-19. Rev. Corp. Finance Stud. 9: 622-655.

Vissing-Jorgensen, A. (2019). Central banking with many voices: the communications arms race. In: Conference Proceedings, 23rd annual conference of the Central Bank of Chile. Central Bank of Chile, Santiago.

Zaremba, A., Kizys, R., and Aharon, D.Y. (2020). Volatility in international sovereign bond markets: the role of government policy responses to the COVID-19 pandemic, SSRN Working Paper No. 3716549, Amsterdam.

Supplementary Material: The online version of this article offers supplementary material (https://doi.org/10.1515/jbnst-2020-0063). 